Portland State University

PDXScholar

8-16-1996

\title{
Liang Qichao, Hu Shi, and Democracy in China
}

Leslie Ann Burgoine

Portland State University

Follow this and additional works at: https://pdxscholar.library.pdx.edu/open_access_etds

Part of the History Commons

Let us know how access to this document benefits you.

\section{Recommended Citation}

Burgoine, Leslie Ann, "Liang Qichao, Hu Shi, and Democracy in China" (1996). Dissertations and Theses. Paper 5081.

https://doi.org/10.15760/etd.6955

This Thesis is brought to you for free and open access. It has been accepted for inclusion in Dissertations and Theses by an authorized administrator of PDXScholar. Please contact us if we can make this document more accessible: pdxscholar@pdx.edu. 
The abstract and thesis of Leslie Ann Burgoine for the Master of Arts in History were presented August 16, 1996, and accepted by the thesis committee and the department.

COMMITTEE APPROVALS:

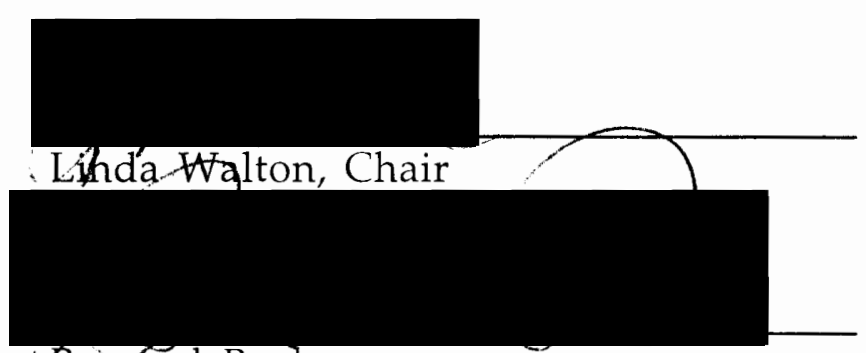

'Bernard Burke

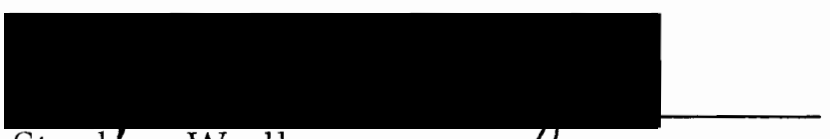

Stephen Wadley

Representative of the Offide of Graduate Studies

DEPARTMENT APPROVAL:

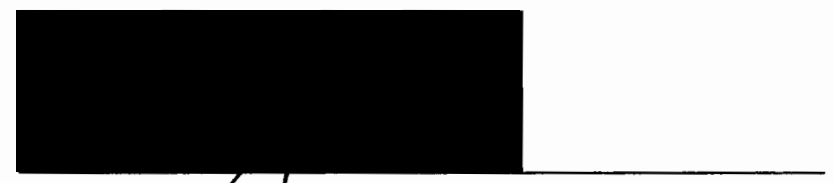

David Johnson, Chair

Department of History 


\begin{abstract}
An abstract of the thesis of Leslie Ann Burgoine for the Master of Arts in History presented August 16, 1996.
\end{abstract}

Title: Liang Qichao, Hu Shi, and Democracy in China

Democracy was one of the many Western ideas that began to be discussed among the Chinese intellectual elite in the last decades of the Qing Dynasty (1644-1911). Liang Qichao (1873-1929), a leader of the 1895-98 Reform Movement, and Hu Shi (1891-1962), a central figure of the 1915-27 New Culture Movement, were two of the most influential proponents of democracy in modern Chinese history. Liang and Hu linked their meanings of democracy with the highest goals for China, national strength and modernity.

Liang Qichao was a revolutionary in advocating the opening of participation in politics to people outside the official government structure through his leadership role in the 1895 Protest Petition. His abundant writings on political events and prescriptions for reform aroused the attention of a wider population than had previously considered national issues. Liang promoted political reforms during the years up to the 1911 Revolution, and then took a direct role in politics in the early Republic.

$\mathrm{Hu}$ Shi expanded on the meaning of democracy to include social and political change. He, too, wrote prolifically and was a key figure in the literary renaissance which aimed to promote education of a broader spectrum of the populace by the use of the vernacular in writing. While 
Hu did not participate directly in political life, he was a constant advocate of democratic institutions and social and cultural progress.

Both Liang and Hu placed a high value on education and tirelessly promoted the exploration of new ideas as the path to modernity. They both harshly criticized the governments under which they worked but preferred gradual reform rather than radical revolution. While their understanding of democracy differed in their generational contexts and personal experiences, they believed that thoughtful participation in politics and society was the core essence of democracy and modernity. 
LIANG QICHAO, HU SHI, AND DEMOCRACY IN CHINA

by

LESLIE ANN BURGOINE

A thesis submitted in partial fulfillment of the

requirements for the degree of

MASTER OF ARTS

in

HISTORY

Portland State University

1996 


\section{TABLE OF CONTENTS}

$\begin{array}{lll}\text { CHAPTER } 1 \quad \text { Introduction } & 1\end{array}$

$\begin{array}{lll}\text { CHAPTER 2 Liang Qichao } & 10\end{array}$

$\begin{array}{lll}\text { CHAPTER } 3 & \text { Hu Shi } & 44\end{array}$

CHAPTER 4 Conclusion: Democracy and Modernity 91

$\begin{array}{ll}\text { EPILOGUE } & 107\end{array}$

$\begin{array}{ll}\text { GLOSSARY } & 110\end{array}$

BIBLIOGRAPHY 113 


\section{ACKNOWLEDGEMENTS}

I would like to thank my thesis advisor, Dr. Linda Walton, for her help, encouragement, and enthusiasm for Chinese history which has made my studies under her direction a stimulating and inspiring educational experience. I would also like to thank my other thesis defense committee

members, Dr. Bernard Burke and Dr. Stephen Wadley, for their insight and assistance. For help in reading and translating Chinese sources and, most importantly, appreciating the language, I would like to thank Dr. Liu Meiru, Xiong Ting, Zhang Feng, and Dr. Wadley.

I am always thankful for my parents, my brother, and my friends in Portland and elsewhere for their steadfast encouragement, supportive commiseration, and genuine companionship. 


\section{A NOTE ABOUT TRANSLATIONS AND ROMANIZATIONS}

Translations of Chinese sources are mine only where indicated. Many of Hu Shi's writings are originally in English; the bibliography lists primary and secondary sources separately.

For the romanization of Chinese names and terms in the text, this paper uses the modern pinyin system, developed in the People's Republic of China and now commonly used in the United States for Chinese words and names. The only exception in the text are the names Sun Yat-sen and Chiang Kai-shek, still more recognizable in their original Wade-Giles rendering. If I have quoted a secondary source that used the Wade-Giles system, I have changed the Chinese words in the quote into pinyin but left the source notation in its original form in the footnotes and bibliography. There is a glossary following the text in which to check the pinyin with the Chinese characters. I have used the simplified Chinese characters, used on the mainland, in the glossary. 


\section{CHAPTER 1}

\section{INTRODUCTION}

Liang Qichao (1873-1929) and Hu Shi (1891-1962) were two of the most influential proponents of political and social reform in modern Chinese history. Their lifetimes span several decades of momentous revolutionary transformation in China, and their lives and thought reflect the intellectual and political changes that moved their country in new directions.

The reform movement of 1895-98 and the May Fourth Movement two decades later, in which Liang and $\mathrm{Hu}$, respectively, played leading roles, saw the first interest in some form of democracy for China. The meaning of democracy changed over time and differed in its interpretations among those who discussed it. In my thesis, I will explore the ideas and lives of Liang and $\mathrm{Hu}$ in order to understand the Chinese perspective on the meaning of democracy. How did Liang and $\mathrm{Hu}$ understand democracy, a Western idea, in both its philosophical and practical aspects? How did they apply these ideas to China and in their own political lives? And what impact did Liang and Hu actually have on the events of their time and later?

In this introductory chapter, I will first review the historical background leading up to Liang and Hu's lifetimes. Then I will discuss democracy as one of many Western ideas explored by Chinese intellectuals in this era. 
For most of its long history, China had been the center of the East Asian political and cultural sphere, and had expected and received the honor and tribute of the neighbors on its periphery. Even when conquered by the Mongols of the Yuan Dynasty (1271-1368) and the Manchus of the Qing Dynasty (1644-1911), China remained Chinese; the Mongols and the Manchus adopted the Chinese political apparatus, as would any newly ruling $\operatorname{Han}^{1}$ Chinese family, and co-opted Chinese culture as a way of legitimizing their rule rather than impose their own on the new dynasty. ${ }^{2}$ When the first Westerners, the Portuguese, arrived off the South China coast in the 1500s, the Chinese succeeded in conducting trade on their own terms under the close scrutiny of imperial officials. ${ }^{3}$ When Europeans and Americans first began to intrude on China's sovereignty in the mid-1800s, China's rulers for the first time had to confront outsiders who would not conform to the Chinese view of the world. 4

1 "Han" is the term used to distinguish ethnic Chinese from minority groups of China, such as the Manchus and Mongols in the north, the Uighurs in the northwest, and the Miao and other groups in the southwest.

2The Mongols and Manchus did make their mark on the Chinese political system and culture during their respective dynasties, but fundamental elements of the culture and society considered essentially Chinese remained dominant.

3 William Theodore deBary, Wing-Tsit Chan, and Chester Tan, eds. Sources of Chinese Tradition. Vol. 2. (New York: Columbia University Press, 1960) 1.

4 For further reading on the early history of foreigners in China, see John K. Fairbank, ed., The Chinese World Order: Traditional China's Foreign Relations (Cambridge: Harvard University Press, 1968); John Wills, Pepper, Guns, and Parleys: The Dutch East India company and China, 16621681 (Cambridge: Harvard University Press, 1974); and Fu Lo-Shu, A 
China's leaders were shocked and deeply troubled by these newest outsiders who challenged their belief in China's cultural and political superiority with their own Eurocentric outlook. The initial challenge was made by military force; therefore the first serious interest in the West was in its technological might. A few of the more adventurous among the Chinese elite decided the West was worth first-hand investigation and went abroad to study. ${ }^{5}$ Most of them concentrated on acquiring the technological knowledge that China lacked in relation to Western countries. China's educated elites were watching their country become increasingly weakened by the Opium Wars and the unequal treaties at the hands of the West and therefore were devoted to the preservation and strengthening of China against invasive Western powers. ${ }^{6}$ Many provincial leaders attempted to incorporate Western technology in arms development and to study science-related subjects such as mathematics in

Documentary Chronicle of Sino-Western Relations (1644-1820) (Tucson: Arizona University Press, 1966).

${ }^{5}$ For further reading on China's nineteenth century interest in the West, see Jane Kate Leonard, Wei Yuan and China's Rediscovery of the Maritime World (Cambridge: Harvard University Press, 1964); Immanuel Hsu, China's Entrance into the Family of Nations: The Diplomatic Phase, 18581880 (Cambridge: Harvard University Press, 1960); and Thomas LaFargue, China's First Hundred: Educational Mission Students in the United States, 1872-1881 (Pullman: Washington State University Press, 1987).

6 For further reading on China's wars and treaties with the Western powers in the nineteenth century, see John K. Fairbank, Trade and Diplomacy on the China Coast (Cambridge: Harvard University Press, 1953); Michael Greenberg, British Trade and the Opening of China, 18001842 (New York: Cambridge University Press, 1951); Gerald Graham, The China Station: War and Diplomacy, 1830-1860 (New York: Oxford University Press, 1978); and Teng Ssu-yu, Chang Hsi and the Treaty of Nanking, 1842 (Chicago: University of Chicago Press, 1944). 
the so-called Self-Strengthening Movement beginning in the 1860s. The slogan of the day was xī xué weì tǐ , zhōng xué wè̀ yòng: Chinese learning should remain the essence, but Western learning should be used for practical development.

China's leaders were not only threatened by foreign invaders, but the latter half of the nineteenth century saw numerous internal rebellions, from the Taiping rebellion of 1851-1864 to the Boxer Uprising of 1900. The primary responsibility for putting down these rebellions rested on provincial leaders, who raised local armies to suppress the rebels. The suppression of ethnic and peasant rebellions, as well as the provincially-led Self-Strengthening Movement, served to enhance and militarize the forces of regionalism. This, of course, meant a weaker Qing central government and foreshadowed the warlord period of the early Republic. ${ }^{7}$

Towards the end of the 1800 s, more and more Chinese leaders came to realize that acquiring Western technology was not enough and that China's weakness was more deeply rooted in its political culture. The most shocking event was China's defeat in 1895 in Manchuria by Japan, historically a tributary state, and the resulting Treaty of Shimonoseki. As the incompetence of Qing rule became more and more apparent, China's entire imperial political system began to be questioned by reform-minded elites both within and outside government circles.

${ }^{7}$ For more on late Qing militarization and regionalism, see Stanley Spector, Li Hung-chang and the Huai Army: A Study in NineteenthCentury Chinese Regionalism (Seattle: University of Washington Press, 1964) and Philip Kuhn, Rebellion and Its Enemies in Late Imperial China: Militarization and Social Structure, 1789-1864 (Cambridge, Mass.: Harvard University Press, 1970). 
A number of China's most insightful leaders began to wonder whether China's weakness was simply technological or whether it lay deeper. More profoundly, they considered what kind of changes China needed to undergo in order to meet the challenge of the modern world. What in China's political, social, and cultural heritage should be preserved and what should be transformed or even thrown out? This is not to say that the Chinese social and political system had remained static in the preceding centuries, for indeed it had not. However, change had been more gradual, and it is no exaggeration to say that the pace of change in the latter half of the nineteenth century, and certainly in the twentieth century, was unprecedentedly swift. China's elite feared the end of Chinese civilization as they understood it. As the severity of the crisis became more apparent to educated Chinese, the scope of their exploration of foreign ideas broadened in order to sustain China. Their utmost concern was the preservation of the Chinese nation, and now the idea that some form of political reform was needed began to be discussed.

A few Chinese who studied abroad in the late nineteenth century were interested not only in Western technology but also in Western culture and ideas. One of the most famous was Yan Fu (1853-1921) , who translated such books as John Stuart Mill's On Liberty, Charles Montesquieu's Defense of the Spirit of the Laws, Adam Smith's Wealth of Nations and, most importantly, Thomas Huxley's Evolution and Ethics. Yan added to his translation of Huxley a commentary and interpretation,

8 See especially Benjamin Schwartz, Yen Fu and the West: The Search for Wealth and Power (Cambridge: Harvard University Press, 1964). 
On Evolution, in which the concept of Social Darwinism introduced Chinese intellectuals to a new way to analyze China's predicament in the world, in terms of a racial and national struggle for "survival of the fittest." Social Darwinism also gave a prescription for progress by means of transforming and strengthening nation and society. These ideas had a tremendous impact in China from that time forward as they underlay nearly all Chinese thinkers' recommendations for progress, from democracy to Marxism, from moderate reformer Liang Qichao to Communist revolutionary Mao Zedong (1893-1976). ${ }^{9}$

The crisis precipitated by the shocking defeat by Japan in 1895 and the accompanying treaty was the impetus for reform at the higher levels of government. The events of the protest petitions submitted in 1895, involving Liang Qichao, can be seen as the first democratic political event in China, as it is the first time that people without official positions felt that they should be allowed to influence government policy. ${ }^{10}$ The dramatic nature of this event and the following reform period of 1895-1898 brought what once were extreme ideas directly to the attention of the highest imperial leaders. ${ }^{11}$ Moreover, most of these ideas were commonly accepted only a few years later; the idea that some kind of reform at the dynastic level was necessary and the idea that people outside of the official

\footnotetext{
${ }^{9}$ For more on the impact of Darwinism in China, see James Reeve Pusey, China and Charles Darwin (Cambridge: Harvard University Press, 1983). 10 Andrew J. Nathan, Chinese Democracy ( New York: Knopf, 1985) x, 46. 11 See Luke K. S. Kwong, A Mosaic of the Hundred Days: Personalities, Politics, and Ideas of 1898 (Cambridge: Harvard University Press, 1984).
} 
structure of the government had a role to play became commonly accepted assumptions.

The purpose, of course, was to strengthen China. Reform-minded Chinese noted that the strongest nations in the world were based on some form of democratic principle, from the republican system with a popular electorate of the United States to the constitutional monarchies of Japan and England, and they began to consider what these kinds of political systems could mean for China. First and foremost it meant opening up awareness and participation in government to the general population; this concept coincided with the Chinese political belief in the harmonic ties between ruler and ruled, ties traditionally maintained by the hierarchical structure of government officials. The idea that communication between ruler and ruled needed repair in order to strengthen the nation was not new, but the idea that general participation, and even protest, could strengthen the nation was definitely foreign.

The discussion of China's modernization often orients tradition and modernity at opposite and opposing poles; China's traditional social and political system was considered by many to work against its ability to modernize, and modernization was seen as destructive of traditional culture. However, all societies display both elements of their traditional roots and elements of modernity. More importantly, tradition and modernity are not static states of being. Indeed, both the understanding of tradition and the understanding of modernity constantly undergo change and redefinition as societies face new challenges and search for the best 
solutions. ${ }^{12}$ Some historians have written that, as Liang and $\mathrm{Hu}$ related democracy to China's modernization as well as elements of traditional culture, they were "emotionally tied" to the past or that there is a "tension" in their thinking. ${ }^{13}$ Instead, it seems that their effort to meld modern and traditional concepts is a natural and universal adaptation in the face of rapid change.

Nationalism, too, is still being debated in its historical and contemporary contexts. The rise of modern nationalism in China is usually dated to the late nineteenth and early twentieth centuries; peasant nationalism expressed itself in the form of rebellions, and elite nationalism was expressed in the reform and revolutionary movements. It can be argued that the construct of China's enduring social and political history, with its theories of the relationship between the state and the people, suggests that there had long existed an awareness in smaller communities of belonging to a larger political entity, a national identity. ${ }^{14}$ Nonetheless, the newness of the development of Chinese nationalism in

12 See Benjamin I. Schwartz, "Culture, Modernity, Nationalism -- Further Reflections," In Tu Wei-ming, ed. China in Transformation. (Cambridge: Harvard University Press, 1994) 233-253; Michael Gasster, "Reform and Revolution in China's Political Modernization," In Mary Clabaugh Wright, ed. China in Revolution: The First Phase, 1900-1913. (New Haven: Yale University Press, 1968) 67-96; and Paul A. Cohen, Between Tradition and Modernity: Wang T'ao and Reform in Late Ch'ing China (Cambridge: Harvard University Press, 1974).

13 For a historiographical critique of writings on the intellectual history of modern China, see Lung-kee Sun, "Historians' Warp: Problems in Textualizing the Intellectual History of Modern China," Positions: East Asian Cultural Critique 2: 2 (Fall 1994): 355-381.

14Prasenjit Duara, "De-constructing the Chinese Nation," Australian Journal of Chinese Affairs 30 (July 1993): 1-26. 
the nineteenth century rests on the fact that it arose out of confrontation with invading outside forces and that the sentiment was used by political leaders, whether peasant rebels or scholar revolutionaries, to motivate the general population for political and social change. China's modern nationalism was a response to Western and Japanese imperialism, and on the elite level, the threat to the nation warranted reform and revolution.

It was in this context of nationalism and modernity that democracy was advocated; it could be said that democracy was attractive for its connotations of modernity and was pursued in order to serve nationalistic ends. Chinese intellectuals of this period were first concerned with China's strength, and it is only natural that democracy's most important value was its potential for strengthening the nation. 15 While it was agreed that the goal was a strong, modern China and that some form of democracy was necessary, controversy remained over the synthesis of traditional and modern ideas and the institutions that would make the best form of democracy for China.

Liang Qichao and Hu Shi, as the two foremost leaders of their generations, were, at their foundation, patriotic advocates of a strong, modern China. Their understanding and advocacy of democracy differed in their generational contexts and personal experiences but correlated in their shared search for Chinese modernity.

15For the argument that May Fourth intellectuals and others valued democracy as much for its protection of individual rights, see Hung-Yok Ip, "Liang Shuming and the Idea of Democracy in Modern China," Modern China 17: 4 (October 1991): 469-508. 


\section{CHAPTER 2 \\ LIANG QICHAO}

Liang Qichao was born in a small village of the southern province of Guangdong in 1873 into a lower class gentry family. Educated in the Confucian classics at an early age, he showed great promise as a student and his family made every effort to further his education. He passed the provincial-level civil service examinations at 16 and the impressed official examiner offered his sister in marriage, a practice not uncommon in traditional China. ${ }^{1}$ However, this was the highest level degree that Liang would attain, never passing the triennial metropolitan exams in Beijing.

Nonetheless, his achievements were revolutionary and brilliant. This study will focus on the periods of Liang's early activism, 1895 to 1898, and his exile in Japan, 1898 to 1911, showing the development of his political ideas. I will conclude by following his struggle to put those ideas into practice when he held various political offices in the early Republic, 1912-1919. In 1919, Liang dropped out of politics and concentrated his energy on scholarly work at Qinghua University in Beijing.

1895 to 1898: Liang's Early Activism

Liang began studying at a prestigious academy in Canton at age 14 in 1887, and in 1890 he was introduced to Kang Youwei (1858-1927)2 , a radical

${ }^{1}$ Chang Hao. Liang Ch'i-ch'ao and Intellectual Transition in China, 18901907 (Cambridge: Harvard University Press, 1971) 58.

2For more on Kang Youwei, see Hsiao Kung-chuan, A Modern China and a New World: K'ang Yu-wei, Reformer and Utopian (Seattle: University 
scholar whose ideas upset the assumptions of Liang's earlier training in which the Confucian conception of politics and the social order were unquestioned. Kang's extreme ideas, "as though with the thunderous sound of the surf, and the roar of a lion"3, were, in Liang's words:

...like a cold shower for me, or a blow right at the head with [the Zen master's] staff, suddenly depriving me of my defenses, leaving me dazzled without knowing what to do. I was both shocked and delighted, embittered and remorseful, frightened and uncertain. 4

Liang quit the academy and studied under Kang for four years, a period of intellectual and political excitement in which the development of Liang's political ideas began.

The Petition of 1895

At the time Kang went north in 1895 to promote political reform, Liang, now 22, followed. They were both in Beijing to take the civil service examinations when the Treaty of Shimonoseki, ending the Sino-Japanese War (1894-1895), was signed; this was a shocking and humiliating defeat for China at the hands of a former tributary kingdom. Kang and Liang capitalized on the incensed fervor the conclusion of the treaty incited, and

of Washington Press, 1975) and Chang Hao, Chinese Intellectuals in Crisis: Search for Order and Meaning (1890-1911) (Berkeley: University of California Press, 1987). In addition to Kang, Chang Hao's work focuses on Tan Sitong (1865-1898), Chang Taiyan (1868-1936), and Liu Shipei (18841919).

3Philip C. Huang. Liang Ch'i-ch'ao and Modern Chinese Liberalism (Seattle: University of Washington Press, 1972) 12.

${ }^{4}$ Nathan, Chinese Democracy 47. 
convinced over 1200 examination candidates ${ }^{5}$ to join them in petitioning the court to protest the terms of the treaty and request institutional reform.

The petition of $1895^{6}$ was the beginning of an intensified reform movement for Kang and Liang. This protest in 1895, termed by Liang as "the first step in the movement for popular government,"7 can be seen as the first democratic political event in China; 8 it was the first time that a group of people outside the official government structure was mobilized to exert pressure on the government and push for policy changes. ${ }^{9}$ The significance of this petition cannot be overstated; formerly the right to submit memorials to the emperor was the special privilege of government officials. The idea that people without government posts should be allowed to oppose and influence government policy was the first step on the road to opening participation in politics to a wider Chinese populace. The opening, however, was still small and elite-dominated, as the

5Chang 60; Nathan, Chinese Democracy 46.

6In Chinese it was called the Göngchē Petition; gōngchē means public vehicle, a term used for examination candidates who were entitled to travel to Beijing on public transportation. Joseph R. Levenson, Liang Ch'ich'ao and the Mind of Modern China (New York: Harper and Row, 1959) 19.

7Levenson 19.

8 Nathan, Chinese Democracy $x$.

${ }^{9}$ The petition included a broad range of requested reforms, including the rejection of the peace treaty, the transfer of the capital and administrative reforms, reform of the civil service examinations, expansion of the education system including the establishment of agriculture and business schools, revision of local government laws, and suggestions regarding public health and poor relief among others. Ssu-yu Teng and John K. Fairbank, eds. China's Response to the West: A Documentary Survey (New York: Antheneum, 1975) 148. 
participants in the 1895 petition were highly educated aspiring scholarofficials.

After submitting the petition, the reform movement took on an expanded scope. Kang Youwei and Liang continued to petition the court but also moved to gain the broader support of the gentry-literati by organizing study societies and publishing newspapers. For a short while in the summer of 1895, the Self-Strengthening Study Society (Qiáng Xuéhui) gathered in Beijing and a branch society was set up in Shanghai. Liang was appointed secretary of the Beijing society and edited a daily newspaper known as The Chinese and Foreign News (Zhōngwài Gōngbào). The paper contained only a few essays about current events and within three months was shut down (along with the Self-Strengthening Study Society) due to imperial court interference, but it had gained popularity among gentry-official circles in Beijing and gave Liang his first foray into journalism. 10

\section{Modern Journalism and Political Reform}

A key to further broadening popular interest and influence on political events was the development of journalism in China, and Liang Qichao was a pioneer in this field. Traditional Chinese journals were copies of the imperial government's memorials and edicts distributed for the information of bureaucratic officials. Similar local newspapers were issued from provincial capitals, and popular newssheets were available whenever there was a fire, earthquake, riot, or sensational trial to report.

${ }^{10}$ Chang 61-62; Huang 24-25. 
Western missionaries can be credited with transforming traditional forms of news in China into modern propaganda in the early nineteenth century, when they printed and distributed their own periodicals as a method to win over new converts. The traditional purpose of news and instruction in China was intended to maintain and stabilize society, not to change it, to teach people, not to mobilize them. It was not long, however, before various Chinese revolutionary leaders also began to use journals and newpapers to unite and arouse their followers. ${ }^{11}$

In addition, a non-governmental press emerged in the latter part of the 1800 s to fill the demand for business information and, therefore, was concentrated in the treaty ports like Shanghai and Hong Kong. These newspapers focused on trade and commerce, staying away from major political issues. However, China's military defeat by Japan in 1895, resulting in Japan's opening of additional treaty ports on the Chinese coast, was reported in the business papers and incited a broader discussion of national politics among Chinese merchants. The implications of imperial policy and foreign domination of coastal cities now were a direct concern of Chinese traders as well as the scholar elite. As the politically concerned audience widened further in the cities, the political journal was created, primarily featuring editorial essays on both domestic and international

11 The history of journalism in China, see Nathan, Chinese Democracy 133151. See also Roswell S. Britton, The Chinese Periodical Press, 1800-1912 (Shanghai: Kelly and Walsh, 1933) and Lee-hsia Hsu Ting, Government Control of the Press in Modern China, 1900-1949. (Cambridge, Mass.: Harvard University Press, 1974.) 
politics. This revolution in the field of journalism in China began in 1895 with Liang's leadership.

After failures in organizing additional study societies, Kang and Liang chose to carry out their movement through the publication of another newspaper. A number of reform-minded Shanghai elite invited Liang to edit a newspaper based there, and Liang began to write first for Current Affairs (Shíwù Bào) and then for New Knowledge (Zhīxinn Bào). It was his essays written for these journals which first made Liang's name known as widely as Kang's.

Kang and Liang were radical and modern not simply because they advocated reform, for reform had been advocated at various times in previous dynasties, but because they didn't look solely to historical precedents for their models of regeneration. They were radical because they considered adapting foreign political methods to aid China's progress and because their modernity was characterized by their reconciliation of the use of foreign political ideas with China's own tradition. Their specific radical modern method is the advocacy of popular participation in government.

Liang Qichao wrote in the Shíwù Bào in 1896:

Why is it necessary to reform?......Those who advocate no change frequently claim, 'We follow the ancients, follow the ancients.' Do they know that from prehistoric, ancient, medieval and modern times down to the present day, there have been many hundreds of thousands and myriads of changes?...Those who insist that there is no need for reform still say, 'Let us follow the ancients, follow the ancients.' They coldly sit and watch everything being laid waste by following tradition, and there is no concern in their hearts...The Book of Changes says, 'When there is exhaustion, there should be 
change; after a change there is cohesion; when there is cohesion things will be long-lasting.' 12

This quote shows that the method of Liang's argument includes a reconciliation of the traditional Chinese respect for historic precedent with the need for the adaptation of foreign ideas in order to meet the challenge of current conditions. Some historians have asserted that Liang is "emotionally tied" to Chinese tradition or that there is a "tension" in his thought and writings due to his tendency to blend Chinese tradition with the reforms he advocated; however, as others have pointed out, most societies possess both traditional and modern characteristics. China may be unique in the age of its written canonical traditions and its reverence for them, but it joins the company of many other nations in believing that modernization in the twentieth century necessitates western-style reforms.

\section{Teaching in Hunan Province}

Liang left Current Affairs in late 1897 and was invited to be the chief lecturer on Chinese studies at the newly established School of Current Affairs (Shíwù Xuétáng) in Hunan province, where a reform-minded governor and a group of progressive scholar-officials were instituting new schools, study societies, newspapers and businesses. Liang continued to develop his ideas through writing and even became involved in Hunan politics by submitting a number of petitions to the governor. In one of those petitions to the Hunan governor, Liang wrote:

If we wish now to reform thoroughly, we must begin by establishing communication between the sentiments of those

12Teng and Fairbank, "Doc. 42: Liang Ch'i-chao on Reform, 1896." 154-155. 
above and those below. If we wish to establish communication between the sentiments of those above and those below, then we must revive the intentions of the ancients, adopt Western institutions, and stress the authority (quán) of the local districts...[Toward these ends] we must develop the knowledge of the literati...and fix the limits of authority (quán). What do I mean by delineating authority? The Westerners separate discussion and legislation (yishi) from execution (xingshi). The legislators (yishi zhirén) have the authority to decide upon general procedures (dingzhāng) but do not have the power to carry out such. The executors have the authority of implementation but do not have the authority of deciding upon general procedures. When something is about to be done, the assemblymen get together and deliberate over its advisability. If they approve, then they will discuss its procedures. After the procedures have been drafted, they are given to the administrator (yousi) to carry out. The administrator may not arbitrarily change them. If, in carrying them out, obstacles and difficulties are encountered, then he will inform the assemblymen who will in turn discuss and change them. The Westerners' laws for this reason are constantly changing and are refined with each change, becoming ever better adapted to the people's interests. This is because the assemblymen are elected by the people. ${ }^{13}$

Liang's aim to blend Chinese and Western political concepts in his prescription for reform are clear in this petition. His work in journalism and education in order to promote more educated political participation is not only modern but is consistent with the Confucian "intentions of the ancients" to revive "communication between the sentiments of those above and those below."

Liang had advocated gradual reform when he was writing in Beijing and Shanghai, but he became frustrated by the slow progress his gradualist approach had been achieving. In Hunan Liang's lectures and activities took an increasingly radical turn. Not only did his lectures include anti- 
Manchu sentiment and ideas regarding popular rights, he even submitted a petition to the Hunan governor proposing that, if necessary, he should declare Hunan independence. He argued that if the central government could not be forced to reform, then Hunan could secede, carry out its own reforms, and lead the eventual recovery of all China from foreign aggression. 14 Thus Liang put himself among the most radical reformers of the period.

As could be expected, a number of the Hunanese elite became alarmed at Liang's radical teachings and launched an ideological counterattack. Before the reaction became a total defeat for the Hunan reformists, in early 1898 Liang fell ill and had to leave Hunan for medical treatment in Shanghai.

The Hundred Days of 1898

By this time, reform activities began to intensify again in Beijing due to heightened concern over the Russian demand to lease Dairen and Port Arthur and the recent seizure of Jiaozhou Bay by Germany. After his treatment and a short rest in Shanghai, Liang left once again for Beijing to join Kang.

Kang Youwei was able to gain an audience at the imperial court and temporary influence primarily due to a factional split within the court. One faction was centered around the young Emperor and the other around the aging and officially retired Empress Dowager who, due to her long tenure and experience, was still referred to on important matters by a 
number of the more powerful court officials. The weaker Emperor's faction was receptive to many of Kang's reformist suggestions, and the Emperor issued a series of edicts during the summer of 1898, later known as the Hundred Days of Reform. Conservative members of the court became alarmed at what they perceived to be progressively extreme reform edicts and persuaded the Empress-Dowager to reinstate her tutelage, thus bringing an end to the flurry of proclamations. ${ }^{15}$ Liang did not play a leading role in the Hundred Days, but he had been appointed to head a newly founded translation bureau and received imperial permission to establish a school for training translators. ${ }^{16}$ His close association with Kang Youwei meant that he, too, had to flee arrest and execution at the reform movement's abrupt end. Liang took his exile in Japan.

Exile in Japan: The First Phase, 1898 to 1902

Liang's move to Japan coincided with an increase in the number of Chinese students choosing Japan as their destination for study abroad. In the 1870s, when the first Chinese students were sent abroad to study under government sponsorship, they went to Europe and America with the goal of acquiring skills in Western science and technology. In the late 1890s and early 1900s, Japan became more attractive due to both its geographical and cultural proximity. More importantly, however, was the change in the intellectual climate; in addition to studying science and technology,

${ }^{15}$ For an in-depth study of this movement, see Luke K.S. Kwong, A Mosaic of the Hundred Days, footnoted above. 16 Huang 27. 
Chinese students were open to a broader scope of interests, especially politics. Liang's arrival in Japan was a strong stimulant to the overseas Chinese intellectual climate there. ${ }^{17}$

Liang's first journal began publication barely two months after his arrival and was the well-known Journal of Disinterested Criticism (Qingyi Bào). This journal came to an end in 1901 due to a fire, but in early 1902 the bimonthly New Citizen (Xïmmín Shuō) was established and continued publication until 1907. These journals were widely read among overseas Chinese and were so popular that they were smuggled into China and circulated hand to hand, making Liang the leading voice for reform in China. These years were the peak of Liang's influence, and the peak was high. While he himself wrote with discouragement, "My daily work consists of enslaving myself with pen and paper, producing empty words that are of no help in (overcoming) current national difficulties," most readers were inspired by him. He did not write in the heavy scholarly language but used a more vivid new style with "a sharp pen and overflowing emotion (that) deeply moved me", wrote one. "Even Napoleon at the height of his power could not have captivated a larger number of men in his armies than the numberless youths whom Liang held under the influence of his pen", one of Liang's translators asserted. To various people, he "stimulated my patriotic fervor" and was "a

17 Kang also initially fled to Japan but was forced to leave in 1899 due to diplomatic pressure from the Qing government. (Chang 133.) This also marked the point at which Kang's and Liang's ideas began to diverge more sharply, Kang becoming more conservative and Liang more progressive, soon eclipsing Kang's influence through his provocative essays. 
fountain of wisdom" who "completely capped the times." A literary critic wrote in the 1950s that "every Chinese intellectual in the last fifty years has been influenced by Liang Qichao." Hu Shi wrote that Liang's essays were "capable of making us dance, of making us weep, of arousing us to a determined enthusiasm."18

Education was the primary method by which Liang believed that the populace could be moved to participate in politics and make China a stronger nation. Through his writings, Liang introduced new Western ideas to his readers and wrote of the political changes he hoped to see in China. He also undertook the founding and head mastering of the Great Harmony High School (Gāoděng Dàtóng Xuéxiào) in Tokyo in 1899, established to provide higher education for the children of overseas Chinese, and financed by Chinese merchants in Japan.

Liang also maintained his involvement in more directly political activities. Kang Youwei and Liang both thought of the human and financial potential of their contacts with millions of overseas Chinese, and soon after Kang left Japan in 1899, he organized the Protect the Emperor Society (Băohuáng Huì) in Canada as the formal organization of the reformists, of which Liang was an important member.

\section{Liang and Sun Yat-sen: Reform or Revolution}

At about the same time, another important overseas Chinese figure rapidly gaining a large following was Sun Yat-sen, whose revolutionary Revive China Society (Xingzhōng Hui) had been active for a number of 18Nathan, Chinese Democracy 47-48. 
years. ${ }^{19}$ Sun's followers mainly resided in the treaty ports, the secret societies in south China, and the overseas Chinese communities, but the potential of the newly politically-oriented student groups began to attract his attention too. Kang and Liang had to decide whether to regard Sun's group as possible allies or as rivals. In a more fundamental sense, they had to consider whether they were advocating reform or revolution, a dilemma that all Chinese political activists had to contend with at this time.

Before 1903, Liang was more inclined toward cooperation than Kang. Kang believed that reform was the best direction for China, and it seems that Liang, rather than disagreeing with Kang ideologically over the reform or revolution approach, primarily was interested in the quickest way to change and therefore was more open to different methods. As discussed above regarding his rather radical activities in Hunan but his support for the more moderate reform movement, Liang held both radical and gradualist viewpoints at the same time. Therefore it seems less accurate to characterize his entire political outlook in Japan as radical than to say that his ideas included both reformist and revolutionary tendencies.

Kang became upset that Liang was cooperating with Sun Yat-sen and ordered Liang to go to Hawaii to garner support there for Kang's Protect the Emperor Society. Liang was already well-known in Hawaii due to his popular writings, and while there, Liang joined the local triad society and

${ }^{19}$ For further reading on Sun Yat-sen, see Harold Z. Schifflin, Sun Yat-sen and the Origins of the Chinese Revolution (Berkeley: University of California Press, 1968) and Martin C. Wilbur, Sun Yat-sen, Frustrated Patriot (New York: Columbia University Press, 1976). 
was elected its leader. Many of the triad members then came to support the Protect the Emperor Society, taking local support away from Sun Yat-sen. Sun sent Liang an angry letter, charging him with betraying an agreement between them before Liang's trip to Hawaii. Liang's response could be seen as indicative of his typical wavering or as political coalition-making. He replied that his political approach was a multifaceted one, essential for the rapidly changing circumstances. He asserted that the ideal of popular government could be attained by capitalizing on the current fervor over the controversy surrounding the Empress-Dowager's choice of an heirapparent for the Emperor. He even assured Sun that in principle he still supported anti-Manchuism, characteristic of Sun's nationalist revolutionary approach, and urged him to be flexible and cooperative. Liang even proposed a plan wherein a popular uprising could be staged against the Empress-Dowager's regime in order to protect the emperor, and after overthrowing her faction, the ideal of republicanism could be realized by electing the emperor president! 20 For Liang, the exact form of government was not a matter of principle but of expediency. Not only does this episode point to Liang's flexibility in approach, one could say, but it also exemplifies the fact that, in his mind, democracy was not the most important characteristic of reform. Democracy was so strongly associated with political modernity that it sometimes seemed that superficial democratic methods were sought only to make China appear modern; if true democratic methods were unable to strengthen China at a particular

20Chang 139-140. 
moment, other more effective means were readily considered by Liang and other reformers and revolutionaries of the time.

In his historical analyses, however, Liang would not label an event democratic simply for the convenience of citing an historical precedent. In 1901, referring to the sage-kings of Chinese antiquity, he wrote:

The abdications of Yao and Shun are the premier instances of generous action in Chinese history. It is not only the standard old scholarship which unites to praise them. Thus, the modern "people's rights," "great harmony" group, too, does not fail to cite Yao and Shun to prove that China had a democratic system in antiquity. Their intent cannot but be called laudable. [Yet] I consider democracy to be a world universal principle. Where universal principles are concerned, one must not consider as a matter of any importance whether or not the ancients previously applied it. Thus, the abdications of Yao and Shun actually have no bearing on the modern doctrine. That is, even if Yao and Shun really did abdicate, that still is entirely different from modern democracy. 21

As contrived as Liang's proposal for electing the emperor may sound, it was true that Liang and some of his associates were coordinating a popular uprising in the name of protecting the emperor, resulting in the short-lived Hankou uprising of 1900. One of Liang's co-conspirators was in contact with Sun and his revolutionist group and hoped to coordinate revolts in the Yangtze Valley with those of Sun's group in southern Guangdong province. 22 This shows that although Liang generally advocated gradual change through reforms, he occasionally took part in more radical activities. And even though Liang's actions sometimes seemed to discount his commitment to democratic methods of

21 Levenson 92.

22Chang 140-141. 
government, this was due to his impatience to see some kind of reform for China. If not appropriate at the immediate time, democracy remained important in Liang's vision of a modern China in the future.

\section{Liang's New Citizen}

In 1902, Liang began writing his most influential journal, New Citizen (Xinmín Shuō). This series of articles, mostly written before his travels in the United States in 1903, display his vision for the development of a strong China.

The title, Xĩnmín Shū, is significant. The term xinmín (literally, new people) is a central term from one of the Confucian classics, the Great Learning, connoting that the basis of Confucian statesmanship rests in moral education and renovation of people. This traditional concept certainly underlay Liang's thinking, and he reinterpreted it to fit the requirements of the current time. ${ }^{23}$ He wrote:

By xinmín, I do not mean to suggest a distinction between a new person and the one who makes him new. Instead, I mean for each of our people to renovate himself...He who cleanses himself of the contaminating filth of the past is said to be renovating himself (zixin). Those who can rid themselves of the contaminating society of the past are called new citizens (xinmin). 24

In his Xinmín Shuō, Liang wrote of the new moral and personal characteristics that a renovated Chinese people, new citizens, would need to embody in order to strengthen China.

23Chang 149-150.

24Huang 65. 
Liang's theory of China's new citizens and the state also had a strong Western influence, specifically drawn from social Darwinism. Liang defined the state as an organic whole composed of its citizens, and it is the quality of the citizens that will make up the quality of the state. Liang wrote:

If there are new people (xinmin), we do not worry that there is no new institution, new government, or new state. The state is formed by an aggregation of the people. The people in the state are like the four limbs of the body. (Therefore if) you wish to achieve security, wealth, and prosperity, then (you) cannot but teach the way of new people. 25

Therefore, the people must be renewed and strengthened in order to build a strong state.

One of the most important concepts that formed the foundation for Liang's definition of a new citizen is that of qún, or unity. Liang contended that it is the essence of morality to strengthen group cohesion and to promote group interest. 26 This idea is intertwined with that of nationalism, a major theme of most Chinese reformists and revolutionaries of the time; indeed Liang is viewed historically as one of the first to arouse modern Chinese nationalism. Liang's concept of qún holds both modern and traditional characteristics; while traditional Chinese political culture holds that group interests have primacy over individual interests, Liang gives his own interpretation a non-traditional

${ }^{25}$ Tim Sung Wook Shin, The Concepts of State (Kuo-Chia) and People (Min) in the Late Ch'ing, 1890-1907: The Case of Liang Ch'i-ch'ao, T'an Ssut'ung and Huang Tsun-hsien (Ph.D. dissertation. University of California, Berkeley, 1980) 119.

26Chang 151. 
twist: that the specific interests and moral values of a group change over time and must evolve to meet the needs of current circumstances. Liang believed that the Confucian moral ethical standpoint of the ruler-subject relationship was miserably outdated and unsuited to withstanding the modern imperialism of the West. He wrote in the New Citizen:

The motivating force (of modern international competition) stems from the citizenry's struggle for survival which is irrepressible according to the laws of natural selection and survival of the fittest. Therefore the current international competitions are not something which only concern the state, they concern the entire population....The international competitions of the past which were the concerns of the rulers and their ministers would subside after a period. But the current international struggle will last forever because it is constantly a matter of concern for the life and property of the people. ${ }^{27}$

Thus a united, nationalist citizenry is essential for the defense of China against Western imperialism.

While Liang considered it the duty of the government and officials to educate the citizens, he also recognized the potential energy of the Chinese people. Liang wrote in The New Citizen:

If we want to strengthen our nation, it is necessary to examine the way all other nations have achieved and to select eclectically the best things from them in order to correct our shortcomings...(the) people's morality (míndé), people's knowledge (mínzhî) and people's energy (mínli) are the real sources of politics, scholarship and technology. 28

Liang's view of nationalism and citizenship can be examined through the term for citizenry, guómín (literally, the nation's people). According to Liang's modern concept of citizenry, the state is the public

27Chang 163.

28 Shin 122 . 
property of the people who make up the state. As Liang wrote in the New Citizen:

The state is an aggregation of the people as a whole. If it is the people of a state who govern, legislate, and plan for the interest of the whole state and stave off the troubles which might afflict the state, the people then cannot be bullied and the state cannot be overthrown. This means citizenry. ${ }^{29}$

Liang's definition of citizenry alludes to a democratic form of government as well as shows the importance he places on national unity for the purpose of saving China. Liang's definition of a modern citizenry contrasts that of the traditional definition of the ruler and subject; sovereignty rests in the people rather than in the ruler.

However, it is necessary to distinguish between democracy and liberalism, for liberalism implies individualism, an orientation that Liang did not support. Liang did set forth his definition of liberty in the New Citizen, but it is necessary first to explain a problem of language. Liberty is one of those English words that does not have a direct equivalent in Chinese, and its closest translation carries a negative connotation instead of a positive one in the English sense. The Chinese term, ziyóu, means "to act as one wishes," whereas the English term conveys the idea of freedom from bondage or arbitrary rule. Liang expressly defined liberty in the positive sense, writing that "liberty is a universal principle, a necessary condition of life, and is applicable everywhere."30 He went on to say that the two most important aspects of liberty for China were popular

29 Chang 164.

30Huang 69. 
participation in government and national sovereignty. 31 The strengthening of China as a nation is always of paramount importance.

Before 1898, Liang had understood Western democratic ideas in terms of the Mencian ideal of "primacy of the people." In Japan, after further study of Western and modern Japanese thought, he developed his ideas regarding the difference between the Mencian ideal and Western democracy, writing:

Someone asks: 'Mencius is said to be the founding father of Chinese democracy. May I venture to ask whether the democracy of which Mencius spoke is the same as the democracy of which Western thinkers speak today?' I answer, 'It is different! It is different! The democracy of which Mencius spoke concerned protecting the people and caring for the people...Protecting the people is to treat them as infants. Caring for the people is the same as tyranny in that it invades the people's right to liberty. The people prize their independence; they treasure their rights. They are not to be interfered with.' 32

It would be easy to mistake this quote of Liang's as his advocacy of individual rights and liberties, but it is clear from the preponderance of his other writings that his concept of rights does not refer to those of the individual against those of the state. In The New Citizen, Liang clarifies:

Freedom means freedom of the group, not individual freedom. In the age of barbarism, individual freedom prevails and no collective freedom develops. In the civilized age, the freedom of the group develops while individual freedom decreases. ${ }^{33}$

Freedom of the group refers to freedom from imperialist domination by outside groups. Individual freedom, Liang feared, could lead to social and

31Huang 69-70.

32 Huang 60.

33Chang 202. 
political anarchy which would weaken the nation's stance against foreign incursions.

That is not to say that Liang did not have any concern for individuals, for he was certainly concerned about the personal characteristics of China's new citizens. "Self-mastery means self-conquest and self-conquest means strength. With self-conquest and strength, how free one is!"34 But the purpose for cultivating these modern personal characteristics was for the collective good of the society and nation, not simply for the individual's own sake. He wrote in the New Citizen:

The combination of fractions of rights will make up the right of a totality. All the individual senses of right will add up to a collective sense of rights of the whole nation. Thus cultivation of the sense of national right must start with the individual...The citizenry is an assemblage of individual citizens. The national right is the collection of individual rights...The strong citizenry then make up a strong state; the weak citizenry make up a weak state; ...the citizenry in possession of rights makes up a state with national right...A citizenry without a sense of right, when confronted with foreign incursion, is like a withered tree in a storm. 35

\section{The Later Years in Japan, 1903-1911: The Trip to America and After}

In early 1903, Liang made a trip to America which strongly affected his ideas for the direction of change for China. Liang's trip to the United States in 1903 shifted the emphasis in his thoughts about democracy. After having studied Western democratic institutions and ideas for a number of

34 Chang 204.

35Chang 195. 
years, Liang's direct observation of American society and overseas Chinese communities there left him disillusioned.

Liang first of all observed that the people with the greatest ability did not take on leadership positions in politics, resulting in a predominance of mediocre presidents. Liang held critical views of a number of features of the American political system, such as the frequency of elections, which he saw as wasteful and corrupting, and the fact that the goal of many politicians was popularity rather than the solution to problems. He was awed by America's prosperity and dynamic economic growth but alarmed by Theodore Roosevelt's jingoistic speeches. ${ }^{36}$ These observations served to strengthen his concern for China's stance against imperialism and his belief that the unity of citizens was necessary for China's survival.

His observation of American Chinese communities, discovering that they had not progressed politically even though they existed under a more advanced political system, heightened his pessimism toward the ability of Chinese people to govern themselves in the near future. While the Chinatown in San Francisco published a number of newspapers and journals, evidence of a relatively high rate of literacy, Liang saw the community as plagued by corruption, infighting, inefficiency, and poverty and concluded that the Chinese people "were simply not ready for democracy."37 Liang sadly wrote:

Freedom, constitutionalism, republicanism: these are but the general terms which describe majority rule. But China's majority, the great, the vast majority of Chinese, are as I have described them

36Chang 239-244; Levenson 69-76.

37 Huang 79. 
here. Were we now to resort to rule by this majority, it would be the same as committing national suicide. Freedom, constitutionalism, republicanism -- this would be like wearing summer garb in winter, or furs in summer: beautiful, to be sure, but unsuitable. No more am I dizzy with vain imaginings; no longer will I tell a tale of pretty dreams. In a word, the Chinese people must for now accept authoritarian rule; they cannot enjoy freedom...Those born in the thundering tempests of today, forged and molded by iron and fire -- they will be my citizens, twenty or thirty, nay, fifty years hence. Then we will give them Rousseau to read and speak to them of Washington. ${ }^{38}$

After his return, Liang wrote in The New Citizen that "for years I have been intoxicated with the idea of a republic...(but) all my life I have challenged received opinion, so I am not afraid now to challenge my former self. ${ }^{\prime 39}$

\section{Enlightened Despotism}

Liang had tentatively believed that a constitutional monarchy could work in China, but after his trip to the U. S., he came to doubt that the population possessed an adequate level of education and political experience for its implementation. He also noted that China lacked the institutional background, such as a clearly defined judicial system. He refuted his acceptance of constitutional monarchism in his long article of 1905, "On Enlightened Despotism."

Liang came to see a need for temporary autocratic leadership in China due to "internal conflicts" of "small groups" which could undermine the general good of society. Previously, he had believed that

\footnotetext{
38 Nathan, Chinese Democracy 60.

${ }^{39}$ Nathan, Chinese Democracy 61.
} 
individual interests and those of the whole society would naturally coincide, but now he believed instead that internal individual competition necessitated a strong government to impose order and solidarity. Order and solidarity, of course, was essential for a nation's ability to face external, or international, competition. ${ }^{40}$ In defending authoritarian rule that is enlightened, Liang wrote that "even if a governmental system nearly robs the people of the bulk or all of their liberty, it is a good system provided that it is founded on the spirit of meeting the exigencies of national defense."41 After a period of education under strong rule, an educated citizenry would achieve a higher civic consciousness in which their individual interests would automatically coincide with those of the state. 42 Clearly again, the form of government was less important than its nationalistic purpose. Once democracy lost its potential for strengthening China, Liang was ready to redefine it or put it off indefinitely for a time when China achieved strength and modernity.

National survival and domestic harmony would be the top concerns of Liang's enlightened despot. 43 He now proposed that enlightened despotism (käiming zhuãngzhì) with a consultative assembly should be established as a transitional and preparatory phase to a representative constitutional system. Liang reasoned that the important criterion of government was not unchecked power but whether the government was enlightened; that an enlightened monarchical despotism was far more

\footnotetext{
40 Chang 251-254.

41 Huang 82.

42Nathan, Chinese Democracy 62.

43 Huang 99.
} 
desirable than a democratic despotism. ${ }^{44}$ He seemed to temporarily abandon even his most modest advocacy for democratic systems, but later he would revise his stance once again to campaign for the constitutionalist movement begun in 1906.

Liang's views on nationalism were moderated at this time also. While many Chinese reformers and revolutionaries tended towards antiManchu nationalism, especially Sun Yat-sen's followers, Liang saw the long-term potential for China's fragmentation if this narrow definition of nationalism was followed. Earlier, Liang was not clear in his ethnic definition of nationalism, but true to his concern for China as a whole, now he clearly stated his advocacy of a "broad nationalism" that would unite China's ethnic minorities against imperialist aggression. 45

\section{The Constitutional Movement}

After 1903, the topics of Liang's writings covered more concrete issues, such as finance and constitutional law. 46 Increasingly, Liang seemed to envision himself taking on a more concrete role in political leadership. When the Qing government announced plans to study the formation of a constitutional monarchy in 1906, looking to Japan as a model for modernization after that nation's surprising victory over Russia in Manchuria, Liang established an organization that would express

\footnotetext{
${ }^{44}$ Frank Fe Wong, Liang Ch'i-'ch'ao and the Conflict of Confucian and Constitutional Politics (Ph.D. Dissertation. University of Wisconsin, Madison, 1965) 107-108.

45Chang 261-262.

46 Huang 99.
} 
popular sentiments and educate the people politically in preparation for constitutional government. He did not take an official position in the organization as he was still on the wanted list of the Qing court, so he sought the support of leading Han and Manchu officials and of prominent local gentry. The organization was established in Tokyo in 1907 under the name Political Information Society (Zhèngwén Shè). 47

The organization's espoused purpose was to work for a rapid transition to constitutional government through peaceful and orderly means. Its constitution called for the early convening of a national legislative body and the institution of responsible government, the establishment of the "rule of law" and the independence of the judiciary, the development of local self-government, and the equality of China with foreign nations. An undeclared purpose, in Liang's mind, was to counter the growing influence and activities of the more radical revolutionaries. 48 He hoped that this new organization could bring together reformers of more moderate opinions.

Within a few months, the Political Information Society headquarters were moved to Shanghai, and the society focused on coordinating the most recently established constitutional associations and submitting petitions to the court urging the prompt convening of a parliament. Liang once again reaffirmed his belief in the positive renovating energy of the people, writing in 1908:

47Huang 104.

48Huang 105. 
Our country's people may say, right now the word from the emperor about setting up the constitution has already been pronounced several times. The responsibility is the government's...the so-called supervisory system trickles down to me. I'd rather wait than pursue...Personally I would say that this attitude is very stupid (Wú qiè wèi wèi cǐ yánzhě qí bù zhì yì y̌̆ shèn y̌̃). No matter how strong the words from the government, they might not be honest. Also we don't know when they will put it into practice. Even if they're honest, they may not act soon. And if the driving force is from the government and not the people, then the result will be insignificant...Government and the people have a very close relationship. The people's supervision of the government cannot be lackadaisical or the government will do as it pleases. In this way (with the supervision of the people), good politics will occur. 49

Though Liang writes of the people's role as supervisors of the government, he still regards constitutionalism as a way to strengthen the government by stating that the emperor can benefit from a constitution.

Whether this is regarded as a conflict between or syncretism of Confucian politics and western constitutionalism is a matter of debate. It has been asserted that Liang tended to see the writing of a constitution as a western method for carrying out traditional Chinese principles. In the Mencian tradition, the ruler was held responsible for the welfare of the people, and in this regard constitutionalism was a western system for the implementation of this Chinese principle. 50

Although the energy for reform is most vigorous from below and in this way reform is promoted in a democratic way, guidance and authority

49 Liang Qichao, "Zhengzhi Yu Renmin" (Politics and the People), Yinbing Shi Heji (The Complete Works from the Ice-Drinker's Studio) 3 (20) ; 1718. (My translation.)

50Wong 37-38. 
still rested in the government. In 1912 after the establishment of the Republic, Liang wrote:

The main purpose of constitutional government is to achieve a compromise and reconciliation of contending forces. There are three primary areas of government where this reconciliation must be accomplished: 1 . reconciliation of national sovereignty with people's rights 2. reconciliation of executive power with legislative power 3. reconciliation of the central government with provincial government. 51

Liang hoped for orderly change as the purpose of reform or revolution remained the salvation of China in the imperialist world, and for this reason he believed in a strong central government, as his preamble to the 1912 draft constitution of the Progressive Party shows:

The Republic of China shall be unified forever and its sovereignty shall be exercised by such organizations as are prescribed by this constitution...The sovereignty of the Republic is vested in the state (central government) and is not vested in the people. 52

Throughout his career, Liang's critics accused him of inconsistency and opportunism. In fact, he agreed, writing of himself that he "had too few convictions (and) would often be carried away by events and abandon positions he had held."53 A more sympathetic view would be that he always hoped to "do as much as possible within existing circumstances." 54

Unfortunately for Liang, one of the petitions of the Political Information Society proved to be too radical for the court even to consider. Kang Youwei, working with Liang and the society behind the scenes, drafted a petition signed by his followers that proposed the immediate

\footnotetext{
51 Wong 201.

52 Wong 206.

53 Nathan, Chinese Democracy 48.

54 Huang 4.
} 
convening of parliament and implementation of constitutional government, the ousting of all eunuchs, eradicating Manchu-Han differences, and moving the capital to south of the Yangtze River. ${ }^{55}$ In short order, imperial decree banned the Political Information Society and demanded the arrest and punishment of its members. Since the original goal was to be a legitimate organization working for reform within the system, the now-outlawed society fell apart.

Liang then tried working with other domestic-based constitutional groups. Provincial assemblies were established in late 1909, and they soon called for a national congress in order to speed the establishment of constitutional government. They gathered in Shanghai and sent 33 representatives to Beijing to petition for the timely founding of a parliament. After a number of petitions, initial refusal and later compromise by the court, Liang and the provincial leaders established the Society of the Friends of Constitutional Government (Xiànyǒu Huì) in early 1911 with branches in nearly all provinces and membership of their top provincial leaders. Perhaps inclusive of too many disparate views and ambitions, this society too disintegrated with the onset of the revolution later that year.

While Liang had been advocating moderate reform during the past five years, he was nonetheless thickly involved with assorted revolutionaries during the Qing overthrow in 1911-12, primarily out of a

55Huang 106-107. 
concern for preventing political disintegration and foreign intervention. 56 Liang and a few of his associates attempted to coordinate a constitutional monarchy following the Wuchang uprising of 1911, but Kang and Liang as well as the various provincial constitutionalists were not unified. ${ }^{57}$ In the end, the military strength of Yuan Shikai and his Beiyang Army proved to possess the strongest power base, took control, and a republic was established. 58

Liang's Political Activities in Republican China: 1912-1919

Although Yuan Shikai effectively based his rule on his military power, he still needed significant support from the intellectual elite. The revolutionary intellectual leaders intended to establish a republic, and a constitutional government was meant to provide a basis for unifying regional factions. Liang understandably felt that he had a role to play in the new government, confiding to his brother in 1909 that he felt there could be "no hope for China's future" unless he "returned to take the reins

56Ernest P. Young, "The Reformer as a Conspirator: Liang Ch'i-ch'ao and the 1911 Revolution." Approaches to Modern Chinese History. Ed. Albert Feuerwerker, Rhoads Murphy, and Mary C. Wright (Berkeley: University of California Press, 1967).

57Huang 109-110.

58 For further reading on the early Republic, see K.S. Liew, Struggle for Democracy: Sung Chiao-jen and the 1911 Chinese Revolution (Berkeley: University of California Press, 1971); Ernest Young, The Presidency of Yuan Shih-k'ai: Liberalism and Dictatorship in Early Republican China (Ann Arbor: University of Michigan Press, 1977); George T. Yu, Party Politics in Republican China: The Kuomintang, 1912-1924 (Berkeley: University of California Press, 1966); Ch'i Hsi-sheng, Warlord Politics in China, 1916-1928 (Stanford: Stanford University Press, 1976). 
of government."59 However, Liang lacked a significant and organized base of support of his own.

At the urging of some of his closest followers, Liang decided to ally himself with Yuan, reasoning that if he worked with the strongest power, he could have the most decisive influence. He apparently seemed to hope that Yuan could be fashioned into his ideal of an "enlightened despot," for by the early spring of 1912, he was addressing Yuan in his letters as "enlightened ruler."60 Yuan seemed to appreciate having on his side Liang's prestige as well as his practical advice on law and finance and upon Liang's return to China in November 1912, Yuan awarded him a monthly stipend and an additional sum for a moderate conglomerate party that Liang was working to establish. ${ }^{61}$

In fact, when Liang returned to China in late 1912, he was still at the height of his popularity and his support was highly sought after by many groups. However widely respected he remained, his real influence on the already existing and competing power centers was limited by a lack of organizational unity. Liang joined the newly formed Progressive Party (Jinbù Dăng), a merger of earlier parties ${ }^{62}$, but was only one of its nine executive members. ${ }^{63}$

Liang's political stance at this time can be seen in a speech he gave in the spring of 1913. He rejected the methods of Sun Yat-sen's Nationalist

${ }^{59}$ Huang 117.

60Huang 118-119.

61 Huang 120.

62 For the amalgamation, see Levenson's footnotes on pages 174 and 188 . 63Huang 121. 
Party (calling it a "rowdy party"), worried about the dangers of "mob rule" and "anarchy," and emphasized the necessity of working within existing possibilities. As for Yuan Shikai, Liang said that although "our party is not satisfied with a single measure of the Provisional Government, ... we force ourselves to support this government... in order to await the formation of a permanent government and to attempt gradually to reform the government." His central purpose would be to "calmly and watchfully supervise" the government. ${ }^{64}$ This pragmatic stance is consistent with his views since 1903, viewing democracy and his "new citizenry" as a distant ideal; current circumstances demanded a strong central government that would gradually undergo reforms and lead to representative government. After the weakening of the Nationalist (Guómíndăng) majority in the legislature following the assassination of its leader in 1913, the Progressive Party was able to appoint a number of its prominent members to high cabinet posts, including Liang as Minister of Justice. In this position, Liang attempted to confirm the rule of law by establishing the independence of the judicial branch of government. Liang posited that "to cultivate the rule of law," it was essential to instill in everyone the "respect for the law" that could only be earned by its independence from interference from military authorities. ${ }^{65}$ Liang moved not to completely rebuild a new judiciary nor to revert to the old system but instead to gradually strengthen the new imperfect, but already existing, legal system.

64 Huang 122.

65 Huang 125-126. 
Liang, however, did not get very far in his work with the judiciary. Several months later, the day after the committee drafting the constitution presented its work, Yuan ordered the dissolution of the Guomindang and two months later, January 10, 1914 formally dissolved the legislature. He announced a revised constitution on May 1, giving himself dictatorial powers. Liang, thus, was rendered powerless, but Yuan wanted to keep Liang involved in his government, appointing him to head the Bureau of Currency.

Liang had not had much hope in the legislature before its dissolution, as it could not seem to rise above factional struggles. Now he was even more disheartened but nonetheless forged ahead in his new financial post, attempting to make whatever progress could possibly be made. Here, too, however, Liang found that he could not overcome entrenched interests to enact the reforms he desired, and left his post in the Bureau of Currency at the end of the year. Six months later, Yuan persuaded him to join a new committee for drafting a constitution, but Liang nervously moved to Tianjin as Yuan was hinting at restoring the monarchy with himself as emperor.66 Liang was actively involved with provincially-based anti-monarchists 67 , but when Yuan died on June 6, 1916, his monarchist movement also expired and a few months later the legislature was reconvened under the Provisional Constitution of 1912.

Though Liang was aware of the failure of his earlier efforts in politics and was already considering withdrawing from public life, the 
failure of Yuan's monarchical movement renewed fresh hope that progress in constitutional government could finally be made. 68 Unfortunately, however, partisan strife in the legislature continued, and the elections of 1918 proved the weakness of China's constitutional system. Liang had no real power to make changes; the force of persuasion was not enough without military power. As China slid quickly into a period of warlordism, Liang withdrew from politics in 1919 and devoted his efforts to education and scholarship until his death in 1929.

Liang's political beliefs wavered, over the course of his lifetime, between reform and revolution as well as democratic and authoritarian methods, but he was consistently committed to social progress for China. As Liang's prescription for strengthening China evolved over time and was always tailored to meet the needs of current circumstances, so was his definition of democracy. He was inconsistent in his ideas for specific democratic forms that would ensure the people's role in the government, but he firmly believed in modern democratic ideals of popular education and political participation. Liang was dedicated to the political modernization of China, and his definition of democracy remained under this nationalistic purpose.

68Huang 133-134. 


\section{CHAPTER 3}

HU SHI

Hu Shi was born in 1891 in Shanghai, the youngest son of a minor official in the Qing dynasty. His early home life was somewhat unsettled due to his family circumstances. His mother was his father's much younger third wife (the previous two had died); when Hu Shi was born, his mother was only 18 and his father was $50 .{ }^{1}$ When Hu's father died in 1895 , his young mother was left to depend on the stepsons by her late husband's second marriage for her own and her young child's support. The family earned their living by running small businesses in Shanghai and Hankou and, while Hu Shi's childhood was not spent in poverty, he did grow up in an atmosphere of financial and family tension. ${ }^{2}$ Even so, both of Hu's parents had a strong positive influence on him; though his father died when $\mathrm{Hu}$ was not yet four, Hu was left with his father's books and writings. ${ }^{3}$ And under the difficult domestic circumstances of his youth, it is understandable that the mother-son relationship was a strong one. While his personal aspirations sometimes conflicted with his duty

${ }^{1}$ Jerome B. Grieder, $H u$ Shih and the Chinese Renaissance: Liberalism in the Chinese Revolution, 1917-1937 (Cambridge: Harvard University Press, 1970) 7.

${ }^{2}$ Grieder, $\mathrm{Hu}$ Shih 8-10.

${ }^{3}$ For his father's writings and commitment to the rational humanism of Song Dynasty (960-1279) Neo-Confucianism and that influence on Hu Shi, see Greider, Hu Shih 13-17, 19. 
towards his mother ${ }^{4}$, he often wrote affectionately and sentimentally about her later in life. He remembered her as embodying the traditional virtues of the Chinese wife and mother: modesty, integrity, forbearance -- "my mother's greatest gift," Hu stated ${ }^{5}$, and a strong sense of responsibility towards her husband's family. He wrote in his autobiography that his mother "was able to endure only because she had in me a bit of her own flesh and blood to sustain her. She entrusted all her aspirations to my remote and unfathomable future." ${ }^{\prime 6}$

Hu Shi's future would be one of superb achievement, earning him national and international esteem, even though many of his aspirations for China remained unfulfilled. In examining Hu's ideas on democracy, this chapter will first explore his educational experiences and then will concentrate on his activities and writings from the time he returned to

${ }^{4}$ Most notably the circumstances of his arranged marriage to an uneducated woman from his father's ancestral village. See Greider, $H u$ Shih 11-12, 351-354 and Chou Min-Chih, $\mathrm{Hu}$ Shih and Intellectual Choice in Modern China (Ann Arbor: University of Michigan Press, 1984) 58$80 . .$. After much soul-searching, he eventually gave in, saying, "If we are to lead we must obey the old conventions...Ours is an intermediate generation which must be sacrificed both to our parents and to our children. Unless we would lose all influence, we must marry as our parents wish, girls selected by them for us, whom we may not see before our wedding day -- and we must make society happier and healthier for our children to live in. Let that be our reward and consolation." Lewis Gannett, "Hu Shih: Young Prophet of Young China," The New York Times Magazine (March 27, 1927) 10. The second main issue that troubled $\mathrm{Hu}$ regarding his mother was her devotion to Buddhism, which $\mathrm{Hu}$ considered superstitious and unscientific.

${ }^{5} \mathrm{Hu}$ Shih, "Untitled Essay." In Living Philosophies (New York: Simon and Schuster, 1931) 238.

${ }^{6}$ Grieder, $H u$ Shih 10-11. 
China in 1917 until he left China, almost permanently, in 1937 as the war with Japan consumed all thoughts and energies of China.

\section{$\underline{\text { Hu Shi's Early Studies }}$}

A component of Hu's early learning that would have great importance for his later fame was his introduction to vernacular fiction. While serious Confucian scholars held the writing of classical poetry a worthy pursuit, they considered reading or writing vernacular fiction, especially novels, disreputable and immoral because they entertained themes of romance, intrigue, and even eroticism. However, many literate Chinese secretly spiced up their reading time with popular novels or short stories, and Hu Shi's family was no exception. Hu accidentally found a worn portion of The Water Margin at his uncle's house and instantly became hooked on Ming (1368-1644) and Qing dynasty fiction. "From that time on I devoured every novel known in our community and in the near-by villages." 7 Some years later, as a leader of the literary revolution in 1917, Hu recalled his experiences translating the archaic prose into the colloquial language when he read these stories to the women of the household as they did their sewing. ${ }^{8}$

It was Hu's mother who oversaw his education when he was a young boy, insisting, as his father had before, that his teachers explain the meaning of the texts he studied rather than only requiring the customary

${ }^{7} \mathrm{Hu}$, Living Philosophies 243.

${ }^{8}$ Grieder, Hu Shih 19-20. 
method of rote memorization. ${ }^{9}$ Notwithstanding her respect for traditional Chinese values, she encouraged Hu to seek a "modern" education in Shanghai. ${ }^{10}$

Studies In Shanghai, 1904-1910

Hu Shi was only twelve in the spring of 1904 when he traveled to Shanghai, accompanying one of his half-brothers who needed treatment for tuberculosis, 11 "armed only with a mother's love, a habit of study, and a little tendency to doubt." ${ }^{12}$ He had been advised by his half-brothers that he should not waste his time on the classical curriculum to prepare for the civil service examinations since they were coming under increasing attack (the exams were abolished in 1905). So between 1904 and 1908, Hu Shi studied in schools where classical learning was supplemented by Western studies, such as English and mathematics.

Shanghai at this time was rapidly changing from a port city concerned primarily with trade to a city of intellectual ferment. It was a center for the development of modern newspapers and political journals in China, as discussed in the previous chapter, and the prime spot for the smuggling of banned political journals (like Liang Qichao's New Citizen) into China by students returning from Japan or the West. Hu knew little of international affairs or China's place in them before his arrival in

\footnotetext{
${ }^{9}$ Chou 3.

${ }^{10}$ Grieder, Hu Shih 13.

${ }^{11}$ Chou 5.

${ }^{12} \mathrm{Hu}$, Living Philosophies 246.
} 
Shanghai, but he quickly absorbed the all-encompassing importance of current events into his studies.

$\mathrm{Hu}^{\mathrm{s}} \mathrm{s}$ introduction to Western ideas, including democratic ones, came in several forms, both in his school life and in his outside reading. He read Yan Fu's translations of Huxley's Evolution and Ethics, Mill's On Liberty, and Montesquieu's Defense of the Spirit of the Laws, and while $\mathrm{Hu}$ complained that Yan's classical writing style was "too refined," 13 the impact of the ideas presented in these books on the intellectual philosophy of revolutionary China was, as noted in the introductory chapter, immense and long-lasting. Hu later wrote:

In the course of a few years many of the evolutionary terms and phrases became proverbial expressions in the journalistic writings of the time. Numerous persons adopted them in naming themselves and their children, thereby reminding themselves of the perils of elimination in the struggle for existence, national as well as individual...Two of my schoolmates bore the names "Natural Selection Yang" and "Struggle for Existence Sun"...Even my own name bears witness to the great vogue of evolutionism in China. I remember distinctly the morning when I asked my second brother to suggest a literary name for me. After only a moment's reflection, he said, "How about the word shi (fitness) in the phrase 'Survival of the Fittest'?" I agreed and, first using it as a nom de plume, finally adopted it in 1910 as my name. ${ }^{14}$

As a way of looking at China's present condition, evolutionary ideas were intricately bound with China's conception of progress and modernity. Evolutionary ideas had a profound and enduring effect on Hu's ideas throughout his life.

${ }^{13}$ Grieder, Hu Shih 26.

${ }^{14} \mathrm{Hu}$, Living Philosophies 248. 
Like all young intellectuals of the time, Hu read Liang Qichao's contraband journals. Of these readings, $\mathrm{Hu}$ wrote years later in his autobiography:

It was those essays (Liang's essays and biographical accounts of European thinkers in the New Citizen) which first violently shocked me out of the comfortable dream that our ancient civilization was self-sufficient and had nothing to learn from the militant and materialistic West except in the weapons of war and the vehicles of commerce. They opened to me, as to hundreds of others, an entirely new vision of the world. ${ }^{15}$

Liang not only introduced $\mathrm{Hu}$ to Western ideas but also to a more diverse selection of Chinese philosophy than is usually given attention. Hu read Liang's summary of the history of Chinese thought, General Circumstances of the Development of Chinese Scholarship, and noted that it was this which "caused me to know that China had learning beyond (that found in) the Four Books and the Five Classics."16

Hu Shi studied in three different schools during his time in Shanghai. In 1906 he entered the China National Institute (Zhongguo Gongxue), the third and most radical of the schools he attended. The Institute had just been founded that year by a group of students who returned from Japan in protest against that government's curtailment of their revolutionary activities there. ${ }^{17}$ The student body included a mixture of students from the Chinese interior, not yet feeling the impact of the

\footnotetext{
${ }^{15} \mathrm{Hu}$, Living Philosophies 247.

${ }^{16}$ Chou 11.

${ }^{17}$ Description of the China National Institute in Grieder, Hu Shih 24-26, and in his Intellectuals and the State in Modern China (New York: The Free Press, 1981) 153-154.
} 
revolutionary times and still dressed in traditional scholar's robes, and many students just returned from abroad, wearing Western or Japanese attire and having cut off their queues in protest against Manchu rule. The founding of the Institute provided that the student body would elect from their own number students to serve in the administration, and during their terms they would be responsible to a council of student representatives. Hu served as the secretary of the student association.

$\mathrm{Hu}$ not only read and studied while he lived in Shanghai but was an active, if not radical, ${ }^{18}$ participant in the stimulating atmosphere of the time. He and a group of students from the China National Institute wrote for a small newspaper, established in 1906, they called The Struggle (Jingyè Xúnbào). Like many other small papers of the time, The Struggle was mainly written in the vernacular for the purpose of "instilling new ideas into the uneducated masses." ${ }^{19}$ While an unspoken function was to promote revolutionary political agitation, the expressed aim of the paper was "to stimulate education, promote popular spirit, improve society and advocate political independence." ${ }^{20} \mathrm{Hu}$ seems to have held to these principles in his contributions for the paper, writing essays against superstition, advocating critical thinking, and reflecting that "my editorial work on this magazine helped me...develop an ability in the use of the living tongue as a literary medium." 21 These goals and $\mathrm{Hu}^{\prime}$ s response to

${ }^{18}$ Chou 17-18.

${ }^{19} \mathrm{Hu}$ Living Philosophies, 249.

${ }^{20}$ Grieder, Hu Shih 29.

${ }^{21} \mathrm{Hu}$, Living Philosophies 249. 
them foreshadow the deepening definition of modernity as something more than the strengthening of the nation in a political sense but as a process that includes social and cultural change.

At about the same time that the China National Institute began having financial difficulties in 1908, so did Hu's family. When some of the more radical students broke from the school and opened a New China National Institute, $\mathrm{Hu}$ did not re-enroll but, due to his personal financial circumstances, instead taught English there. When the branch school remerged with the original Institute, $\mathrm{Hu}$ found a position at a different public school teaching English and Chinese, supplementing his income with private English lessons. ${ }^{22}$ This was not a positive period for $\mathrm{Hu}$. He became immersed in the dispirited mood of his revolutionary friends and spent many nights drinking, gambling, and engaging in other vices offered by the city. "Those years (1909-1910) were dark years in the history of China as well as in my personal history...Despondency and drudgery drove us to all kinds of dissipation," Hu reflected. ${ }^{23}$ After a drunken scrape with the police one evening which landed him in jail for the night, $\mathrm{Hu}$ awoke the next day and, seeing his bruised reflection in the mirror, resolved to set himself straight. With financial help from relatives and friends, he managed to set aside a two-month period of study solely to prepare for the Boxer Indemnity scholarship examinations. ${ }^{24}$

${ }^{22}$ Grieder, $H u$ Shih 34.

${ }^{23} \mathrm{Hu}$, Living Philosophies 250.

${ }^{24}$ Grieder, Hu Shih 35. The Boxer Indemnity scholarship, that sponsored Chinese students' university education in the United States, was established by the U. S. government with funds from its share of the 
The examinations were rigorous, but $\mathrm{Hu}$ was one of 70 who passed. Six transformative years in Shanghai changed him from a pre-teen, accustomed to the company of his mother and aunts, into a mature youth, with notions of China's needs for modernization and enough Western training to win a scholarship for study in America. At the age of nineteen, he embarked for the United States.

\section{Studying in the United States, 1910-1917}

In September of 1910, Hu Shi enrolled in the College of Agriculture at Cornell University conceding to "the belief, then current in China, that a Chinese student must learn some useful art, and literature and philosophy were not considered of any practical use." 25 But the topics of biology and botany were uninspiring to him, and after a year and a half of indifferent study and mediocre results, Hu transferred to the College of Arts and Sciences, changing his major to philosophy. Though he felt much more at home in this field, he seemed to feel some need to justify his move, writing a few years later in retrospect:

Many things are necessary for the salvation of the nation, and which of them ought not be undertaken? But I am by nature suited for only one or two things...I changed my occupation, and again argued points of scholarship and politics...In order to solve the difficulties of the times, study must be appropriate to the times.

indemnity China had to pay after the Boxer uprising of 1900. See Michael H. Hunt, "The American Remission of the Boxer Indemnity: A Reappraisal," Journal of Asian Studies 31: 3 (May 1972): 539-559. ${ }^{25} \mathrm{Hu}$, Living Philosophies 252. 
Who at present can question the appropriateness of an age of flourishing literature? ${ }^{26}$

Hu studied diligently, earning his B.A. degree in February 1914. In the fall of that year he continued his study of philosophy as a graduate student. Upon learning of John Dewey's experimentalist philosophy at Columbia University, $\mathrm{Hu}$ transferred there in 1915 to study under his guidance.

\section{$\mathrm{Hu}$ Shi's Philosophical Orientation}

Hu Shi had a "tendency to doubt" at an early age, and as early as January 1914, he wrote in his diary that he was searching for a "practical philosophy."27 He found it in John Dewey's experimentalism. Dewey's approach to philosophy coincided with Hu's previous inclination to study problems using "pragmatic" standards of judgment.

The first experimentalist idea which attracted him was the definition of Truth as a relative value, having meaning only in specific judgments and always open to re-evaluation due to new experience. The second related concept that appealed to $\mathrm{Hu}$ was the scientific methodology that is inherent in experimentalism's analysis of social and intellectual problems. $^{28}$ Certainly Hu was attracted by experimentalism's universal appeal and utility; because it was "scientific," it was not Western but transcended culture. This method of thinking did not necessitate the

\footnotetext{
${ }^{26}$ Grieder, $H u$ Shih 41-42.

${ }^{27}$ Greider, $\mathrm{Hu}$ Shih 47.

${ }^{28}$ Greider, Hu Shih 47.
} 
complete negation of Chinese tradition but did prescribe a re-evaluation of Chinese history and tradition, in Hu's understanding, allowing a "modern" scientific critical re-appraisal of Chinese culture and traditions. Years earlier in Shanghai, $\mathrm{Hu}$ had written through the words of a character in his novel, The Island of Unchanging Reality:

We can only regret that we Chinese have never been willing to think, and only know how to conform, without holding opinions of our own. That our countrymen have come to their present pass is, in my view, simply the result of this unwillingness to think. So the great Confucian scholar of the Song, Cheng Yi, said, "Learning originates in thought," and these four words are certainly the expression of an imperishable truth. ${ }^{29}$

This passage shows that early on, $\mathrm{Hu}$ had rejected conformity, a tendency that intellectuals of his generation criticized as a negative inheritance of China's traditional culture, in favor of critical thinking and valued its importance for the modern development of China.

Hu was also attracted by the idea of progress that he perceived in Dewey's philosophy. In January 1914, before studying under Dewey, he wrote:

What our country urgently needs today is not novel theories or abstruse philosophical doctrines, but the methods (shuे) by means of which knowledge may be sought, affairs discussed, things examined and the country governed. Speaking from my own experience, there are three methods which are miraculous prescriptions to restore life (q̌̌̌l shéndān):

1. the principle of inductive reasoning

2. a sense of historical perspective

3. the concept of progress 30

${ }^{29}$ Greider, Hu Shih 48.

${ }^{30}$ Greider, Hu Shih 48-49. 
$\mathrm{Hu}$, therefore, was looking for methods with which to restore life to, or modernize, China. His practical philosophy for China incorporated the concept of progress, a sense of historical perspective, and the principle of inductive reasoning. This, for $\mathrm{Hu}$, was the philosophical foundation of modernization.

\section{Hu Shi's Observation of American Political Life}

Just as Hu's involvement in the intellectual and political climate of Shanghai necessarily shaped the development of his ideas, so it was with $\mathrm{Hu}^{\prime}$ s time in the United States. While at Cornell University, he learned about American local government by attending meetings of the Ithaca Town Council, and for a course on American party politics he read every state's legislation on political corruption. $^{31}$ During the 1912 presidential campaign, he subscribed to three New York newspapers, each supporting one of the three major candidates. After listening to a debate between Wilson and Roosevelt, Hu wrote in his diary:

Wilson thought that the government's duty was to get rid of the obstacles to let the people live in freedom. This was what Wilson called "new freedom." Roosevelt thought the government was the supervisor of the people that supported, directed, and protected its people as if they were "newborn babies." Between Wilson and Roosevelt, I follow Wilson. ${ }^{32}$

It is interesting that Hu's description of Roosevelt's political philosophy appears Confucian in its conception of government as supervisor and

${ }^{31}$ Grieder, Hu Shih 52. 32Yang Cheng-pin, The Political Thoughts of Dr. Hu Shih. Translated from Chinese. (Taipei, Taiwan: Bookman Books, 1986) 33. 
protector, and $\mathrm{Hu}$ rejected it. As evidence of $\mathrm{Hu}^{\prime}$ s pacifism and cosmopolitan outlook, $\mathrm{Hu}$ further wrote:

Wilson is the type of idealist that is hard to find today. His political thinking can be regarded as the best product of the Western civilization. He has managed both home and foreign affairs with morality. This is why I call it "of consistency." Consistency means that your words and your behaviors agree, in the past as at the present. It means to do to others what you want others to do to you...And do not do to other countries or people what you do not want done to your own country and people. ${ }^{33}$

While $\mathrm{Hu}$ had rejected Roosevelt's conception of government as supervisor, a view that coincided with Confucian political philosophy, he commended Wilson for his morality, another Confucian political value.

During his years at Cornell, $\mathrm{Hu}$ was active in the Cornell Cosmopolitan Club between 1911 and 1914. At different times he held various positions: chairman of the resolutions committee, president, and delegate to an international congress of similar university clubs which simultaneously represented the Cornell Cosmopolitan Club and the Chinese Students' Alliance. ${ }^{34}$ The club's purpose was to discuss political affairs, exchange ideas, and render intellectual and moral judgments, but it did not aim to be directly involved in politics. Hu's political involvement as a student in these kinds of discussion groups reflects his belief in the correct nature of student activism. An entry in his diary in 1915, after hearing music coming from outside his dormitory room, illustrates Hu's opinion on direct political activism:

33 Yang 34.

${ }^{34}$ Chou 84-85. 
Going to the window I looked down and saw an automobile filled with women, all of them suffragettes. In their midst was a girl playing a flute in a manner melancholy enough to move one's heart. Slowly a crowd gathered. The flute stopped and the girl arose to invite the crowd to a rally that was to be held in front of the library. I went along too. A number of women made speeches, all of them quite good. Suddenly in the crowd I caught sight of Professor John Dewey...the number one figure in philosophical circles in this country. I thought at first that he was perhaps only passing by, but when the speeches were over he...got into the car and drove off with all the women... and then I realized that the professor was helping them in their campaigning. Alas, a scholar of the twentieth century should not act thus! ${ }^{35}$

Hu did not consider public protest appropriate for an intellectual concerned with cultural and social regeneration, but he did consider it his place to make his views known on events in writing. For example, in the fall of 1914 at Cornell, a group of female students petitioned the university president to protest the residence of two black students in their dormitory. The president was planning to make segregated arrangements for the two when Hu sent a protest letter to the Cornell Daily Sun. The editor of the paper did not publish the letter but did, at Hu's insistence, forward the letter to the president. Largely due to Hu's letter, the president denied the petition of the white students. ${ }^{36}$

Hu met many prominent speakers and writers through his activity in the Cornell Cosmopolitan Club. Hu even traveled to Washington, D.C. with a group of delegates and met Secretary of State Bryan and President Wilson, who told them, "I think that this little gathering represents one of the most promising things of modern life, namely, the intimate

\footnotetext{
${ }^{35}$ Greider, $\mathrm{Hu}$ Shih 54.

${ }^{36}$ Chou 86.
} 
intercourse of men who are engaged in studying those things which have nothing to do with international boundaries but have only to do with the elevation of the mind and the spirit." 37

It was sentiments such as these which solidified Hu's sense of modern cosmopolitanism, pacifism and universal humanitarianism. These values contrasted with revolutionary nationalist fervor that he encountered in his years in Shanghai. Hu was a patriot and did believe that a sense of national identity was compatible with a cosmopolitan view; cosmopolitanism, $\mathrm{Hu}$ believed, "is patriotism balanced by a humane outlook." 38 Pacifism also accorded with his belief in reason to solve problems and to progress. Hu made a distinction between patriotism and nationalism. In October 1914, he wrote, "Patriotism is a fine thing but it must be understood that above the nation there exists a higher goal, above the nation there exists a greater community. As Goldwin Smith says, 'Above all nations is humanity."'39

$\mathrm{Hu}$ Shi and the Overseas Chinese Student Movement

A critical event in 1915 tested Hu's commitment to pacifism: the infamous Twenty-One Demands submitted by Japan to the Chinese government, claiming a virtual protectorate over much of northeastern China. The event aroused widespread protests in the Chinese student

${ }^{37}$ Greider, Hu Shih 57.

${ }^{38}$ Chou 89.

${ }^{39} \mathrm{Chou} 89$. "Above all nations is humanity" was the motto of the Cornell Cosmopolitan Club. 
population in America as well as among those in China. Hu's reaction, however, was strikingly calm. His proposals ranged from advocating nonresistance to urging the just and swift execution of international law. He remarked, "My cosmopolitanism should first of all be aimed at Japan. This is called catching the ring-leader." ${ }^{40} \mathrm{He}$ wrote an article titled "A Plea for Patriotic Sanity" for the Chinese Student Monthly in which he stated:

I am afraid we have completely lost our heads, and have gone mad...We are excited, nervous, nay patriotically insane. My Brethren, it is absolutely useless to get excited at such a critical moment. No excitement, nor high-sounding sentiments, nor sensational suggestions, have ever helped any nation. Talking of fighting "on paper" is the most shallow course for us to take, who call ourselves "students" and "capable men." It seems to me that the right course for us students to take at this moment and at this distance from China, is this: Let us be calm. Let us DO OUR DUTY which is TO STUDY...Let us apply ourselves seriously, calmly, undisturbedly and unshakenly to our studies, and PREPARE OURSELVES to uplift our father-land...So I say with all sincerity and with all devotion to China, that it is pure nonsense and foolishness to talk of fighting when there is not the slightest chance of gaining anything but devastation, and devastation, and devastation!...Read this letter carefully before you condemn me. ${ }^{41}$

Nevertheless, Hu was swiftly and sharply condemned. The editor of the Monthly printed an editorial in the same issue in which he criticized Hu's commitment to non-resistance as "rested on the wings (of?) philosophers' fancy and scholars' dreams." 42

Hu's reaction to the crisis may seem to indicate a less than adequate concern with Japanese aggression in China. However, he did write a sharp

${ }^{40}$ Chou 90.

${ }^{41} \mathrm{Hu}$ Shih, "A Plea for Patriotic Sanity: An Open Letter to All Chinese Students," The Chinese Students' Monthly 10:7 (April 1915): 425-426. ${ }^{42}$ Greider, Hu Shih 62. 
rebuttal to "A Friend of China" who wrote a letter to the editor of the New Republic stating that perhaps the Japanese might be taking a "responsible and effective direction of China's affairs" since "China is incapable of developing herself." Hu countered:

In this twentieth century no nation can ever hope peacefully to rule over or to interfere with the internal administrative affairs of another nation...The Chinese national consciousness has exterminated the Manchu rule, and I am sure, will always resent any foreign rule or "direction"...the transformation of a vast nation like China cannot be accomplished in a day...Every nation has the right to be left alone to work out its own salvation. ${ }^{43}$

Still, many thought that $\mathrm{Hu}$ was too often lost in "philosopher's dreams" when dire crises demanded more direct, perhaps military, action. But Hu was convinced of the force of ideas in shaping events, and that people can control their environment by forging new social and political forms. This meant, for $\mathrm{Hu}$, that social and cultural transformation is the foundation of progress and modernity, that modernization is a process of ideas. Because ideas are the basis for any action:

Human tools and institutions had their origin in...ideas...The civilization of a race is simply the sum-total of its achievement in adjusting itself to its environment. Success or failure in that adjustment depends upon the ability of the race to use intelligence for the invention of necessary and effective tools. Advancement in civilization depends upon the improvement of tools. ${ }^{44}$

${ }^{43} \mathrm{Hu}$ Shih, "Communications to American Editors on Japanese Demands: Letter to The New Republic," The Chinese Students' Monthly 10:6 (March 1915) 389-390.

${ }^{44} \mathrm{Hu}$ Shih, "The Civilizations of East and West," in Charles A. Beard, ed. Whither Mankind: A Panorama of Modern Civilization. (New York: Longmans, Green and Co., 1928) 26-27. 
Because tools were created by ideas, ideas had more strength than weapons of war, in Hu's thinking, even in times of national urgency. In late 1914 as the crisis with Japan was becoming more serious, Hu wrote in his diary:

Certainly we cannot but respect the sentiments of those who at the present time desire to strengthen the military in order to save China from destruction, but this is unsurpassed stupidity... What, then, is a fundamental plan? To make our education flourish, to release our forces of salvation (kâizwì dizàng), to promote our civilization, to bring order to our internal politics...In our foreign affairs we should give our strong support to humanism (réndào zhǔyi), firmly denouncing, as individuals and as a nation, the unhuman and unchristian aggressivism of the West, and on the other hand advocating with all our might the doctrines of pacifism, and together with the United States exerting our strength to encourage international morality. Only with the progress of international morality can we really speak of progress for the world, and (only then can) our country begin to enjoy the blessings of peace.

Critics will say that this is to talk of the far distant future, and has no immediate practicality...How can I speak of the distant future? I cannot do otherwise. ${ }^{45}$

This attitude, of course, frustrated impatient revolutionaries of the time, but $\mathrm{Hu}$ was not to be swayed from these convictions. In 1915, he wrote a letter to an old friend in Shanghai:

I believe that the proper way of creating causes at the present time lies in the cultivation of men (shùrén). This properly depends upon education. Therefore I have of late entertained no extravagant hopes, and after returning home I will seek only to devote myself to the task of social education...believing this to be the only (possible) plan for the cultivation of men over a period of one hundred years...I have come to understand that there is no short-cut that can be effective in national or world affairs. ${ }^{46}$

${ }^{45}$ Greider, Hu Shih 67-68.

${ }^{46}$ Greider, Hu Shih 70. 
It is understandable that $\mathrm{Hu}$ Shi would be criticized by many activists for his gradual approach to reform, as had Liang Qichao at times.

In late May 1917, after two years at Columbia University, Hu Shi successfully defended his doctoral dissertation, The Development of the Logical Method in Ancient China. His paper was an exploration of classical Chinese philosophy, particularly the heterodox schools, which was intended to reveal previously unrecognized use of "pragmatic" standards of judgment.

Now that China has come into contact with the other thoughtsystems of the world, it has seemed to some that the lack of methodology in modern Chinese philosophy can now be supplied by introducing into China the philosophical and scientific methods which have developed in the Western world from the time of Aristotle to this day...I have the strongest desire to make my own people see that these methods of the West are not totally alien to the Chinese mind, and that on the contrary, they are the instruments by means of which and in the light of which much of the lost treasures of Chinese philosophy can be recovered. ${ }^{47}$

He set sail for Shanghai from Vancouver, Canada, in late June and arrived July 10. He had been away from China for just under seven years. Hu Shi was now a "returned student" and a prominent member of China's intellectual elite, with a growing reputation and a professorship in philosophy awaiting him at Beijing University.

$\mathrm{Hu}$ Shi had found in his studies and experiences in America a reinforcement of his earlier "inclination to doubt" that he had developed

${ }^{47} \mathrm{Hu}$ Shih, The Development of the Logical Method in Ancient China. 2nd Edition. (1922 New York: Paragon Book Reprint Corp., 1963) 6, 9. First published in 1922, the second edition was published one year after his death. 
during his Shanghai days. In addition, his mood seemed to change to a more positive frame of mind. He wrote that "I arrived in America full of pessimism, but soon...I could not escape the contagion of (the American's) cheerful outlook on life." ${ }^{48}$ His years in the United States of Wilsonian idealism instilled in $\mathrm{Hu}$ a forward-looking belief in the progress of humankind.

\section{Hu Shi and the May Fourth Movement, 1917-1923}

For a few weeks in July 1917, there was an attempt at restoring the Xuantong Emperor (the last emperor, $\mathrm{Pu} \mathrm{Yi}$ ) by a warlord, the military governor of Anwei, who hoped to dominate the government in Beijing. In fact, no one truly had central authority over China, and just before $\mathrm{Hu}$ arrived in Shanghai from the United States in mid-July, the northern militarists reclaimed the city and $\mathrm{Pu} Y \mathrm{i}$ was deposed once more. This episode vividly illustrates the chaotic political circumstances of the Republic, circumstances which continued to frustrate and disappoint Liang Qichao, Hu Shi, and all others who had a vision of real political and social progress in China.

Unlike Liang Qichao, Hu Shi did not intend to take a direct role in political events but rather to remain a step back. He felt his role should be that of observer and critic, one who leads not in politics but in the way of thinking. He was convinced that intellectual and cultural regeneration must precede political reform in order to lay its foundation. He resolved

${ }^{48} \mathrm{Hu}$, Living Philosophies 250. 
"to refrain from talking politics for twenty years" desiring that, in time, "a new foundation for Chinese politics" might be laid. ${ }^{49}$

Of course, it was impossible for $\mathrm{Hu}$ to refrain from commenting on political events. Moreover, even though $\mathrm{Hu}$ did primarily concern himself and his writings with intellectual and cultural developments, these concerns were not, and are not, separate from politics but were intricately intertwined with them. The years 1917 to 1923, a period referred to as the May Fourth Movement, was a time in which political and social change and the conception of modernization took on new dimensions. 50 The literary renaissance, an integral part of this movement and its development, is the event with which Hu Shi's name is most often associated.

The May Fourth Movement is so named because of the student protest which took place on May 4, 1919 in response to China's treatment at the Treaty of Versailles which ended World War I. China had been told by the allies that, upon Germany's defeat in the war, German territorial possessions in Shandong province would be returned to China. However, during the war, Japan had taken control of Germany's territory in Shandong and, due to the allies' inability to forcibly check Japan at that time and the tacit agreements made with other parties by the Japanese

${ }^{49}$ Greider, $\mathrm{Hu}$ Shih 175.

${ }^{50}$ For a full account of the May Fourth Movement, see especially Chow Tse-tsung, The May Fourth Movement: The Intellectual Revolution in China (Cambridge, Mass.: Harvard University Press, 1960) and Vera Schwarcz, The Chinese Enlightenment: Intellectuals and the Legacy of the May Fourth Movement of 1919 (Berkeley: University of California Press, 1986). 
before the treaty conference, the Japanese were allowed to retain their control of Shandong. ${ }^{51}$ Students took to the streets in indignation, not only at the Western nations who allowed the agreement but also in protest against the Chinese delegates who were unable to protect Chinese interests.

Like the 1895 Petition, the events of May 4, 1919 served to broaden political awareness and participation. The demonstrations of 1919 widened further the belief that protest is an honorable expression of intellectuals' concern with political events. In addition, it also served to reinvigorate the discussion of new ideas, as disillusionment with the ability of current leaders to govern effectively led to further questioning of the political progress since the 1911 Revolution.

\section{The Literary Movement}

At age 26, Hu Shi was already well-known among the Chinese intellectual elite. During the year before he returned to China, he submitted a number of articles to the New Youth, including two articles that contributed to the growing literary movement in China. $\mathrm{Hu}$ advocated the use of the vernacular language in not only new-style magazines and newspapers but for all forms of literature. In addition to several attempts at vernacular poetry, Hu Shi's articles in January and

51 For more information on the Shandong question at the Treaty of Versailles, see Russell H. Fifield, Woodrow Wilson and the Far East: The Diplomacy of the Shantung Question (Hamden, Conn.: Archon Books, 1965) and Thomas Edward LaFarge, China and the World War (New York: Howard Fertig, 1973). 
April 1917 promoted the written use of the colloquial language. He explained:

The literary revolution we are promoting aims merely at the creation of a Chinese literature of national speech. Only when there is such a literature can there be a national speech of literary quality...A dead language can never produce a living literature...The function of language and literature lies in expressing ideas and showing feelings.. Those who use a dead classical style will...convert their own feelings into literary expressions of centuries past...If China wants to have a living literature, we must use the plain speech that is the natural speech, and we must devote ourselves to a literature of national speech... ${ }^{52}$

The literary revolution, as it was known, was the latest in a series of movements designed to break down traditional social and political structures. A number of trends in the previous decades led up to this movement: the increasing attention paid to Western learning, like the subjects Hu studied as a teenager in Shanghai; the abolition of the civil service examinations in 1905; and not least of all, the proliferation of journals that aimed to widen knowledge of and participation in government affairs, from Liang Qichao's New Citizen to Hu Shi's The Struggle. Intending to broaden education in the realms of subjects studied and in the ranks of students, the purpose also was to create new social conditions that could be the basis of a new political climate. While a certain level of functional literacy had been attained by merchants and other "lower" or "middle" classes for several centuries, high literature and

${ }^{52} \mathrm{Hu}$ Shih, "Constructive Literary Revolution: A Literature of National Speech -- A National Speech of Literary Quality," in Wm. Theodore deBary, ed. Chinese Sources of Tradition Vol. 2 (New York: Columbia University Press, 1960) 164. 
writing had been the special preserve of the elite who had the time and resources to study for the many years that it took to master the difficult classical language. For the men who could attain this level of literacy and pass the civil service examinations, ${ }^{53}$ the rewards were a government post and the attending political power and social prestige. ${ }^{54}$ The literary movement, by advocating the use of the colloquial language in schools, newspapers, magazines, and other literary pursuits, aimed to break down this traditional barrier between the world of the educated and the less educated. Hu wrote:

The most conspicuous achievement of the year 1919 has been the triumph of vulgate Chinese (baihua) as the recognized instrument for journalistic and literary composition as well as for popular education...The art of writing had long been considered a rare gift of the gods to the favored few. But the advocacy of the baihua has emancipated the youths from this timidity which was the result of the unnatural fetters of an antiquated literary formalism. The spirit of Young China was never at ease in its ancient garments...with the emancipation of the literary form, there has burst forth the youthful spirit...Never before has China had so many new writers; never before have there been so many attempts made at literary experimentation and creation. 55

53 Many women in elite households were well educated, but the civil service examinations were only open to men.

${ }^{54}$ The civil service examination system was a meritocracy in that it was open to anyone (male), and thus it did allow for some social mobility, especially later as merchants became wealthy enough to hire tutors for their sons, and in this way, could raise their family's social standing. However, even though social mobility was possible in this manner, the gulf in education and social standing even between the functionally literate and the literati remained a wide one.

55 Hu Shih, "Intellectual China in 1919," The Chinese Social and Political Science Review 4:4 (December 1919): 348-349. 
Because the literary movement's purpose was, like that of the development of journalism in previous decades, to educate and activate a wider public, it can be seen as a democratization of education in this sense. Its proponents hoped that a wider populace would experiment in reading and writing literature in its emancipated form and think about cultural issues in the process. As Hu Shi wrote:

We have realized at last that certain things must be given up if China is to live. If we really want education, general and universal education, we must first have a new language, a language which can be used and understood by tongue and ear and pen, and which will be a living language for the people. ${ }^{56}$

This literary revolution had implications far wider than in the field of writing, and that was its intention. Hu maintained that "as language is the most important vehicle of thought and of expression, any radical and fundamental change in a national language could not but involve a great change in other phases of social and intellectual life." ${ }^{.57}$ Indeed, by incorporating not only words but also ideas from popular folk culture into the new literature, the movement brought about a "vernacularization of values $^{\prime 58}$ meaning that the experiences and ideas of ordinary people were regarded as worthy of attention. In fact, the literary revolution was one aspect of the greater New Culture Movement in which the traditional "high culture" of Confucianism was discredited and a search for alternative native traditions was undertaken. A vital concern for the

${ }^{56} \mathrm{Hu}$ Shih, "The Renaissance in China," Journal of the Royal Institute of International Affairs 5:6 (November 1926): 271.

${ }^{57} \mathrm{Hu}$, "The Renaissance in China" 273. ${ }^{58}$ Schwarcz 79. 
continuity of Chinese tradition made the study of popular or folk culture of great importance. ${ }^{59} \mathrm{Hu}$ stated in 1933, years later, that the literary revolution

was a movement of conscious protest against many of the ideas and institutions in the traditional culture, and of conscious emancipation of the individual man and woman from the bondage of the forces of tradition. It was a movement of reason versus tradition, freedom versus authority, and glorification of life and human values versus their suppression. ${ }^{60}$

The New Culture Movement (roughly dated 1915-27) represented a shift in intellectuals' focus of modernization from politics to social and cultural development. Near the end of 1919, Hu wrote:

Ever since 1898, the attention of intellectual China has been confined to things political...(but) eight years of bitter failure under a nominal republic has gradually brought young China to the realization that democracy cannot be secured through political changes alone...Democracy...is no more and no less than the sum total of all the democratized and democratizing forces, social, economic, moral, and intellectual. It is this realization which constitutes one of the guiding principles of the new movements in China. $^{61}$

The movement's reinvigorated search for new ideas, political and cultural, fed Hu Shi's optimism about cultural and social developments:

It was the nonpolitical forces -- the students, the merchants, the demonstrations and street orations, and the boycott -- that did the

${ }^{59}$ See especially Lawrence A. Schneider, Ku Chieh-kang and China's New History: Nationalism and the Quest for Alternative Traditions (Berkeley: University of California Press, 1971).

$60 \mathrm{Hu}$ Shih, The Chinese Renaissance, 2nd Edition (New York: Paragon Book Reprint Corp., 1963) 44. These were a series of lectures delivered in 1933 to the Department of Comparative Religion in the University of Chicago.

61 Hu Shih, "Intellectual China in 1919" The Chinese Social and Political Science Review 4:4 (December 1919): 350. 
work and triumphed...let alone the petty political intrigues in Peking and elsewhere -- we still have the masses to educate, the women to emancipate, the schools to reform, the home industries to develop, the family system to reshape, the dead and antiquated ideas to combat, the false and harmful idols to dethrone, the many, many social and economic wrongs to redress. It is in these new channels of activity that Young China, with reawakened hope and vigor, is now working slowly but steadily to rebuild a new foundation for Chinese democracy. ${ }^{62}$

\section{$H u^{\prime}$ s Intellectual Detachment from Politics}

Over the next several years, however, the forces that $\mathrm{Hu}$ had previously called "non-political" became increasingly engaged in political activities. Both Sun Yat-sen's re-formed Nationalist Party and the new Chinese Communist Party (founded in 1921) drew on the young intellectuals' enthusiasm for new ideologies. This trend disturbed $\mathrm{Hu}$. In an essay, "Problems and Isms," Hu warned that abstractions and vague generalizations can obscure concrete problems and solutions. "There is no abstract noun in the world which can comprise all of the propositions of a particular person or group." Because one term can be adopted for different circumstances separated by time or space, "abstractions can be used to deceive people."63 The Chinese Communist Party's dogmatic ideology was opposed to Hu Shi's commitment to methodical investigation of specific problems.

${ }^{62} \mathrm{Hu}$, "Intellectual China in 1919" 351.

63Hu Shi, "Wenti yu Zhuyi." (Problems and Isms.) In Sharon Shih-juan Hou and Chih-ping Chou, eds. Hu Shi Reader: An Advanced Reading Text for Modern Chinese (New Haven, Conn.: Far Eastern Publications, 1990)149-170. Originally published in Chinese in Meizhou Pinglun (Weekly Critic) 31: July 20, 1919. (My translation.) 
In 1922, Hu founded The Endeavor (Nǔli Zhöubào), a magazine which he intended to keep above the fray of political discussions.

However, the writers and editors on this project were committed to a more direct link between cultural and political reform. Certainly, the connection between cultural and social issues and political ones could not really be separated. Hu finally acquiesced, saying:

...now I can stand it no longer. If I come out at the present juncture to speak of politics, although in part I am driven to it by the corruption of domestic politics, in fact I am compelled to speak in large part by the 'new public opinion' of recent years, which 'talks a great deal of isms, but does not study problems.' In talking politics now I am only putting into practice my own proposal to 'study more problems and talk less of isms'...I am greatly dissatisfied with present-day thought and art...The rotten old orthodoxies have been overthrown, but in their place are various wretched new orthodoxies. $^{64}$

The second issue of The Endeavor featured a proclamation entitled "Our Political Proposals" in which was written:

We believe that we must have a practical, clear-cut goal which is intelligible to everybody if we talk of politics. And we believe that the goal of "good government" should be the most modest requirement for the present political reform of China, a goal which is commonly recognized by all the Chinese elite, regardless of what their ideal political institutions are... ${ }^{65}$

Their suggestions included issues such as the reunification of northern and southern governments, the re-establishment of a "legitimate"

${ }^{64}$ Greider, Hu Shih 189.

${ }^{65}$ Translated in Chow 241. See footnote (or Grieder, $\mathrm{Hu}$ Shih, footnote on 190) for the list of signatories. Interestingly, the idea for "Our Political Proposals" originated with an associate of Liang Qichao's, but due to their previous alliances with the governments of Yuan Shikai and other warlords and hence their reputation for political opportunism, Hu and his group did not seek their suggestions or signatures. 
parliamentary institution, the drafting of a permanent constitution, disarmament, and bureaucratic reforms. The document also addressed the major problems of the political climate of the warlord era: large "private" armies funded by foreign loans and heavy domestic levies, a swollen bureaucracy with official posts held by those with powerful connections rather than ability, parliamentary processes fabricated to serve the interests of autocrats, the absence of the rule of law applicable to both politicians and civilians, and the indifference of these governments to the opinions of their critics or the people over whom they govern. ${ }^{66}$ The opening paragraphs stated that no matter what ideal of political organization or ideology, the objective of political reform in China should be "good government."

The minimal significance of 'good government': What we call 'good government' is, in its negative aspect, the existence of proper organs to oversee and protect against all illegal, self-seeking, and madly corrupt officials. On the positive side, we raise two points: 1. Fully to utilize the instruments of politics to plan for the total welfare of the whole society.

2. Fully to tolerate the freedom of the individual, and to love and protect the development of individuality (gèrén xing) ${ }^{67}$

The document went on to propose three "fundamental principles" of political reform: a constitutional government, a 'public government' (göngkāi de zhèngfŭ), and a 'government with a plan' "because we firmly believe that China's great malady is unplanned and aimless drifting." 68

${ }^{66}$ Chow 241 and Greider, $H u$ Shih 190-191.

${ }^{67}$ Greider, Hu Shih 191.

${ }^{68}$ Greider, Hu Shih 191-192. 
$\mathrm{Hu}$ Shi had long been in favor of a strong government, a government with a plan, remarking in 1914 while a student in America, that "The tendency of modern Western political theory is away from laissez-faire and toward intervention by the state." As a student, he also wrote:

The greatest need at present is to fix one's purpose and to establish a fundamental policy...and, when this has been done, to work steadily for a period of twenty or fifty years without faltering. Only then can there be some hope for national salvation. ${ }^{69}$

He regarded European laissez-faire liberalism as a negative response to administrative incompetence rather than a principle of government. In 1923 he called for "political instrumentalism," defining this political approach:

To find the best form of government, to persuade others that it is the best; and having done so to stir them up to insist on having it, is the order of ideas in the minds of those who adopt this view of political philosophy...Government is a tool for us to use, to experiment with, to master and control, to love and cherish, but not something to be afraid of. A government intelligently conscious of its own instrumental potentialities, and, at the same time, subject to democratic control, is the only kind of political machinery worthy of the new age of science and technology. ${ }^{70}$

A number of leaders in the 1920s saw federalism, the granting of a level of autonomy to the provinces, as a potential solution to the problems of a weak central government and the fractious regionalism of the warlord era. Hu Shi concurred, maintaining that Chinese history shows that the

${ }^{69}$ Greider, $\mathrm{Hu}$ Shih 193.

$70 \mathrm{Hu}$ Shih, "Instrumentalism as a Political Concept." In Studies in Political Science and Sociology (Philadelphia: University of Pennsylvania Press, 1941) 3,6. 
country is too large and too diverse to be successfully governed centrally. "To encourage the development of genuine regional authority and thus to enable the various regions to develop the strength that lies latent there, in order to wage war on the warlords and to overthrow them -- this is the meaning of provincial self-government and the purpose of the federalist movement." 71 Hunan promulgated a provincial constitution along federalist lines in 1922, and other provincial leaders discussed federalist ideas. Unfortunately, provincial constitutions and reforms could not overcome the forces of warlordism, and the movement died out. ${ }^{72}$ $\mathrm{Hu}$ 's prescriptions for political reform, though democratic in character, were elitist in the sense that they were intellectual solutions, heavily dependent on intellectual leadership. Despite this elitist bent, $\mathrm{Hu}$ was firmly committed to democratic ideals. He not only saw democracy as embodying certain political institutions, but believed that it was a social and intellectual state of mind. Unlike Liang Qichao, $\mathrm{Hu}$ did not believe that the lack of a well educated populace necessitated a period of political tutelage before the establishment of democratic institutions. Instead, he argued the opposite: that democratic institutions are essential to education

${ }^{71}$ Greider, Hu Shih 195.

72Andrew J. Nathan, Peking Politics, 1918-1923: Factionalism and the Failure of Constitutionalism (Berkeley: University of California Press, 1976) 6. See also John Fincher, "Political Provincialism and the National Revolution," in Mary Clabaugh Wright, ed. China in Revolution: The First Phase (New Haven: Yale University Press, 1986) 185-226; Jean Chesneaux, "The Federalist Movement in China, 1920-3," in Jack Gray, ed. Modern China's Search for a Political Form (New York: Oxford University Press, 1969) 96-137; and William L. Tung, The Political Institutions of Modern China (The Hague, Netherlands: Martinus Nijhoff, 1968) 84-85. 
and will lead to the attainment of democracy in its fully developed sense.

In The Endeavor he wrote:

Looking at the matter in the light of the experience of the democratic nations, we must recognize that democratic institutions are an instrument for the training of good citizens... The reason that democratic institutions can be adopted by other nations is simply because of the fact that the institutions themselves perform an educative function...Any nation which has experienced training through democratic institutions over a long period of time will possess a higher level of civic knowledge and morality than other nations...The spread of civic knowledge is an important condition for the cultivation of civic morality. ${ }^{73}$

While $\mathrm{Hu}$ expected little change from warlord governments, he did not advocate revolutionary action. The purpose of "Our Political Proposals" was to invigorate discussion, and it succeeded in this goal. The main criticism of the document matched the main criticism of Hu Shi: the production of ideas needed to be backed up with action. One critic wrote: "...to rely only on propaganda seems to me still the attitude of scholars, and not sufficiently thoroughgoing...Why not form yourselves into a 'Good Government Party'? If there are only proposals, but no concrete organization, then I fear that these suggestions are merely empty talk and will never be realized in fact." ${ }^{\prime 74} \mathrm{Hu}^{\prime}$ s critics maintained that without direct participation in a political party, true influence is minimal.

In response to critics of the "good government group's" detached stance, $\mathrm{Hu}$ wrote:

The greatest need at the present time is to propagandize this commonplace and general aim, to make the people recognize

${ }^{73}$ Greider, Hu Shih 198.

${ }^{74}$ Greider, Hu Shih 199. 
clearly that our common enemy is the bad government of the forces of evil, and that our responsibility is to wage war against it. Now, and in the near future, we should all occupy the position of mediators, impartial men, judges, and overseers. In the future, after politics have got on the right track, differences in concrete proposals will perhaps force us to organize a political party, but that is another question. ${ }^{75}$

Hu previously had been cautiously optimistic about political parties just after the establishment of the Republic, but later became disappointed in their "narrow attitudes," "mutual intolerance," and "constant bickering." In another essay, "Political Critics and Political Parties," written at about the same time, $\mathrm{Hu}$ posited that there are three categories of political critics. The first category comprise those that follow a particular political party, the second include those who lead a party, and the third are those that are unaffiliated with any party but supervise the entire process. These last are:

...transcendent and independent. They recognize only society and the nation, not parties and cliques. They take a statesmanlike view, not a partisan view. Perhaps by temperament and ability they are not fitted to organize a political party. They can comprehend matters, but not necessarily manage affairs; they can plan, but not necessarily execute; they can criticize men, but they don't necessarily know how to deal with them. They should, of course, exploit their strong points, and certainly they should not try to do what they cannot do well. ${ }^{76}$

It is clear that $\mathrm{Hu}$ felt that he belonged in the third category, the category that creates ideas on which to build politics and political institutions.

Three of Hu's fellow signatories of "Our Political Proposals" were appointed to cabinet posts in the new administration of 1922, but soon this

${ }^{75}$ Greider, Hu Shih 200.

${ }^{76}$ Greider, Hu Shih 201. 
new government, too, became embroiled in corrupt dealings. This fiasco became an embarrassment to the "good government group" and The Endeavor, confirming to $\mathrm{Hu}$ and other like-minded intellectuals that they should remain out of politics. Due to disappointment concerning this incident and an illness which took $\mathrm{Hu}$ out of Beijing for a leave of absence, The Endeavor ceased publication in 1923. For several years, $\mathrm{Hu}$ refrained from directly commenting on political events, publishing instead poetry and culturally-minded scholarly essays in the Modern Critic (Xiàndài Pínglùn), a publication of a group of Beijing University professors.

Hu Shi was distressed by the increasingly militant activities of students during this period. He had consistently believed, since his student days in Shanghai and the United States, that a student's first duty is to study. In late 1925, he wrote:

Imperialism cannot be beaten down by bare fists. The British and Japanese bandits will not die by tens of millions of voices yelling and cursing. Saving the country is the paramount cause. Parading and yelling in a high voice "Down with British and Japanese bandits!" cannot be counted as saving the country. Cutting off a finger to write in blood, committing suicide by throwing yourself into the river or sea, becoming a martyr for your country, all cannot be counted as saving the country. The undertaking of saving the country must have many kinds of talented people. Real preparation for saving the country is to make yourself a useful person with ability...Saving the country must begin with saving yourself. 77

This argument is reminiscent of his response to student activism during his own university days in the United States when he attempted to

77 Hu Shi, "Aiguo Yundong Yu Qiuxue." (Patriotic Movement and Scholarly Pursuits.) Hu Shi Reader 171-198. Originally in Chinese in Modern Critic (Xiandai Pinglun) 2: 39 (Sept. 5, 1925) 5-9. (My translation.) 
persuade his fellow students, after the 1915 Twenty-One Demands from the Japanese, to keep calm and study. This stance reflects not only Hu's aversion to radicalism but also his conviction that intellectuals must hold themselves above the fray of direct political activism in order to work for gradual progress.

During the late 1920s, the Nationalists and the Chinese Communist Party became the dominant opposing political forces in China, promoting their particular brands of anti-imperialism and revolutionary nationalism. Hu was always averse to the Communists' dogmatic attachment to, in his view, overly simplified "isms" that "ignore our real enemies and lead us further and further away from our real objective, the creation of a modern nation."78 Still, the following section will show that Hu was continually frustrated by the Nationalists' scorn for political criticism and their refusal to promote constitutionalism and undertake other political reforms.

Hu Shi's Struggle with the Nationalists, 1927-37

In the summer of 1926, Hu departed China for Europe and the United States, where he spent time at centers of sinological research in Paris and London and lectured at various universities in Europe and America. He returned to Shanghai in the spring of 1927 when labor union activists were under siege from Chiang Kai-shek's troops and cooperating

78 Hu Shih, "Which Road Shall We Take?" translated in T'ang Leang-li, ed. China's Own Critics: A Selection of Essays by Hu Shih and Lin Yutang, with Commentaries by Wang Ching-wei (New York: Paragon Book Reprint Corp. 1969) 20. The real enemies, according to Hu, were poverty, disease, ignorance, corruption, and disorder. 
local toughs. Nationalist troops controlled most of southern China and continued to move north. As northern warlords were weakened, the center of political control shifted from Beijing to Nanjing, where the Nationalists had moved their capital from the south. Shanghai, then, was closer to the new capital. In addition, it remained the center of publishing houses and still offered a number of reputable educational institutions. Returning to China reinvigorated from his travels, $\mathrm{Hu}$ joined a group of scholars in publishing The Crescent (Xinyuè). This magazine offered poetry, literary criticism, and political commentary.

$\mathrm{Hu}$ tolerated the Nationalist government, like the warlord predecessors, as the disagreeable but de facto ruling power, seeing his own position as that of a loyal opposition. He never aimed to overthrow Nationalist authority but sought to enlighten and reform it, very similar to Liang Qichao's goals a generation before. He found, however, that the Nationalist leaders did not appreciate the necessity or function of criticism, constructive though it was intended to be. The Nationalists were hardly more tolerant of divergent views than the Communists, and several times it seemed that it was the clout of Hu's former fellow overseas students, now holding positions in Chiang's government, that kept him out of jail. ${ }^{79}$

In The Crescent, as in The Endeavor, Hu stressed the need for exercising authority through "the proper organs of government." $\mathrm{He}$ wrote in 1929 that if "the basis for lawful government" is truly desired, "the first thing we must do is to draw up a constitution for the Republic of

${ }^{79}$ Greider, $\mathrm{Hu}$ Shih 226, 242-245. 
China." But he was willing to compromise with the existing powers; acknowledging the Nationalists' argument for a period of political tutelage, Hu maintained, "At the very least we must draw up a provisional constitution for the so-called period of political tutelage." ${ }^{80}$ A few months later, he continued:

We want to ask what inconsistency there is between training the people and having a constitution...We do not believe that without a constitution there can be a tutelage government. Without a constitution there can be only a dictatorship. ${ }^{81}$

In another essay the same year, $\mathrm{Hu}$ explained:

Democracy in itself serves as an education. People will inevitably make mistakes when they participate in politics in an early stage, but we cannot stop the participation of the people merely because they do not live up to our expectations. What people need is not specialized knowledge but an experience in participation. The basic concept of democracy consists in a recognition of the reliability of people's common sense...Governing a country is a big business, requiring specialized knowledge to solve social problems. But the participation of people in politics is not a special problem. It does not require the participants to possess specialized knowledge. ${ }^{82}$

This passage shows that Hu's elitism is balanced with a belief in ordinary people's common sense and their potential to learn by experience.

$\mathrm{Hu}$ Shi continued to criticize not only Nationalist policies but the theories of the late founder, Sun Yat-sen, as well. In July 1928, Hu was stripped of his position as a member of the Board of the China Foundation

${ }^{80} \mathrm{Hu}$, "Human Rights and the Provisional Constitution" translated in China's Own Critics 28.

${ }^{81} \mathrm{Hu}$, "When Can We Have a Constitution?" translated in China's Own Critics 37.

82Yang 107. See also the translation in China's Own Critics 33-34. 
for the Promotion of Education and Culture, ${ }^{83}$ the agency which administered the American Boxer Indemnity fund. In the spring of 1929, he was accused of having "overstepped the limit of scholarly discussion and indulged in meaningless quibbling" 84 and was nearly arrested for "false opinions" for "having publicly insulted our late Leader and the Party." 85 Then in 1930, Nationalist authorities made a deal with Shanghai's China National Institute, securing Hu's resignation in exchange for official accreditation of the university by the Ministry of Education. ${ }^{86}$ Near the end of the year Hu returned to Beijing, at 39, as dean of the College of Arts at Beijing University and to head the recently established Compilation and Translation Committee of the China Foundation.

The national crisis in China escalated in 1931 with the Japanese conquest of Manchuria. For its duration from 1932 to 1937, The Independent Critic (Dúlì Pínglùn) was the journal through which $\mathrm{Hu}$ Shi argued for constitutionalism, warned against authoritarianism, and considered the practicability of democracy for China. The editorial introduction stated:

We now begin this magazine because we want to publish our opinions in a timely manner, to be like bait, drawing attention and discussion. The expectations for the readers are the same as for

${ }^{83}$ The Nanjing government abolished the old board and named a new one, even though its charter provided for vacancies in memberships to be filled through election by the other members. Greider, $\mathrm{Hu}$ Shih 241-242. $84 \mathrm{~T}^{\prime}$ ang Leang-li, Preface, China's Own Critics vii.

${ }^{85}$ Greider, $\mathrm{Hu}$ Shih 240-244.

${ }^{86}$ Greider, Hu Shih 245. 
ourselves; we do not expect to obtain total agreement but only expect criticism and discussion that is fair-minded and based on facts. We call this magazine Independent Critic (Dúli Pinglinn) because we all hope to forever have an independent spirit. We will not lean towards any political party, nor worship any superstitions, but use responsible words to present the results of our thinking. This is an independent spirit. 87

During this period, young intellectuals became increasingly frustrated with the Nationalists concentration on combating internal Chinese enemies, in the name of unity, rather than fighting the Japanese. While critics' complaints grew louder, their suppression by the Nationalists increased proportionately.

Even though $\mathrm{Hu}$ was a leading critic of the Nationalists, his own views earned him much criticism in this period, too. He opposed a militant response to Japan until very late, 88 arguing for negotiation, and he also opposed the militant activities of many young intellectuals at this time: "The students' fundamental obligation is to endeavor unceasingly to develop their knowledge and talents. Social progress is bit-by-bit progress, and the strength of the nation depends upon the strength of individuals."89 In addition, some of his readers were disturbed by his use of Japan as an example of a nation that had succeeded in modernization where China had not. $\mathrm{Hu}$, however, was not an apologist for Japan, but he did hold out more hope than most for Japanese self-restraint and the

87"Yin Yan." (Editorial Introduction.) Duli Pinglun (Independent Critic) 1 (May 22, 1932): 2. (My translation.)

88In 1935, when Japan demanded an "autonomous area" comprising five northern provinces, $\mathrm{Hu}$ concluded that China had no alternative but to fight "for self-preservation." Greider, $\mathrm{Hu}$ Shih 254.

${ }^{89}$ Greider, $\mathrm{Hu}$ Shih 257. 
influence upon them of world opinion. Historian Jerome Greider writes: "What is revealed in Hu's writings of this period is the confusion of a mind which shunned violence in a violent age and clung in a time of duplicity to a naive faith in good will, and which stubbornly prized reasonableness above all else in a deranged world."90

Hu's appraisal of China's progress varied according to whether he was comparing it to the West or against China's own former condition. The revolutionaries of 1911, he wrote in the Independent Critic:

...envisioned a free and egalitarian, a glorious and flourishing nation. Twenty-three years have passed, and we are still a thirdrate nation that cannot hold up its head. They dreamed of creating a free people living under a democratic constitution, but twentythree years later there are still not a few who imagine that they have fixed their gaze even higher, who sneer at popular rights and freedom but sing the praises of autocracy and dream of creating a new slavery under despotism! ${ }^{91}$

On the other hand, he was encouraged by the change that had been made, and wrote of those to encourage others. "The China before our eyes is no longer something that can be described by the term 'old society'...To say that we are not yet sufficiently modern is irrefutable. To say that this is still the 'old society'...is to deny reality." 92 He continued in a separate essay the same year (1934):

If in all fairness we reckon up the accounts of the last twenty years and more, in the end we must acknowledge that in the republican period we have made great progress, nor can we fail to recognize that this progress is in large part a result of the blessings bestowed upon us by the liberation effected by the revolutionary trends since 1911. If we clearly acknowledge the achievements secured by the

90Greider, Hu Shih 250.

91Greider, Hu Shih 257-258.

92Greider, Hu Shih 258. 
endeavors of the last two decades, we can overcome pessimism and find the courage we need to move forward...Pessimism and disillusionment can never help us to bear our heavy burden down the long road that lies ahead!93

Of course, the Nationalists used the pretext of the lack of an educated populace to justify their authoritarian "political tutelage." Hu Shi, however, continued to advocate his conviction that democratic institutions were instrumental in educating the population. He argued that democratic government is "government by common sense" (chángshí de zhèngzhi), and despotism, even enlightened despotism, needs "government by especially outstanding men" (tèbié yingjié de zhèngzhì). Therefore, "in a country like ours, lacking talented people, the best political training is democratic constitutionalism, which can gradually broaden (the base of) political authority."94 Furthermore, he argued that national unity, whether physical or psychological, must come from below, through the operation of political institutions designed "gradually to cultivate a centripetal force throughout the nation, and gradually to create a 'public loyalty' (gōng zhōng) in place of the 'private loyalties' (si zhōng) of the present time."95 $\mathrm{Hu}$ Shi wrote in the Independent Critic:

The advantage of democratic politics is that it does not require outstanding talented people, and it will be able to gradually broaden (the base of) political authority (tüguăng zhèngquán), there is room for flexibility; by collecting everyone's ideas (jís $i$ guăngyi), the majority of (simple people) can combine their common sense and enable themselves to deal with politics on a

93Greider, Hu Shih 259.

${ }^{94} \mathrm{Hu}$ Shi, "Zai Lun Jianguo Yu Zhuanzhi." (Another Discussion of National Reconstruction and Authoritarianism.) Duli Pinglun (Independent Critic) 82 (Dec. 24, 1933):2-5. (My translation.) 95Greider, Hu Shih 267. 
basic level; this will give the majority of simple people a chance to participate in politics and train them to safeguard their rights (àih ì ziǰ̀ de quánli). 96

His theory of "kindergarten democracy" follows the logic of democratic institutions as education. He argued that democracy "is but a kindergarten system best suited to train a people inexperienced in politics."97 Furthermore, "Democratic government requires only that a qualified electorate be able to exercise its civic rights to good effect; training of this kind is not difficult."98 He argued, from his observation of political life in the United States, that a democratic system takes into account the political apathy of the majority of the population in that it does not demand of them intensive and relentless involvement in politics that authoritarian systems often do. In addition, when the people do participate, they are expressing genuine support and concern since those who wish to remain uninvolved may do so. He concluded that constitutional democracy "is not an unattainable ideal system, but a system of government by common sense that can, given room to develop, gradually improve and broaden the base of political authority."99

$\mathrm{Hu}$ maintained that political institutions will promote a democratic culture and society. He argued in 1937:

constitutional politics can begin at any time and place, but it must start from the kindergarten level and gradually move up.

96 Hu Shi, "Zai Lun Jianguo Yu Zhuanzhi." (Another Discussion of National Reconstruction and Authoritarianism.) Duli Pinglun 82 (Dec. 24, 1933): 2-5. (My translation.)

97Chou 133.

98 Greider, Hu Shih 267.

${ }^{99}$ Greider, Hu Shih 268. 
Constitutional politics is a habit of life, and the only way to learn it is to take part in this kind of life. 100

Even though he argued that democracy should be implemented at once, he spoke of involving only a minority of the population: chambers of commerce, university faculties and educational associations, bar associations and banking and finance groups, the general labor unions, and the party. ${ }^{101}$ Regarding the debate on the rights of the National Assembly in 1936-1937, Hu wrote:

In the primary state, we should restrict voting rights to those citizens who have received elementary education for at least one year. With the increasing number of educated citizens, the political rights can be extended to the whole nation. This does not intend to take away the voting rights from the majority by the criterion of education level. It is only a strategy to stimulate ordinary people to learn to read and write. 102

He did call on the Nationalist government for a "opening up of political power" (käifàng zhèngquán) to counter their insistence on the dominance of their party above all others. "My common sense tells me: the welfare of the people above all, the life of the nation above all...in the interests of justice, and in order to unify national support, the Nationalist Party should make political power public, and permit the people of the whole nation freely to organize political parties and groups."103

${ }^{100}$ Chou 133.

101Greider, Hu Shih 271.

102Yang 138-139.

${ }^{103} \mathrm{Hu}$, "Zhengzhi Gaige de Dalu." (The Great Road Toward the Reform of Political Institutions.) Duli Pinglun 163 (Aug 11, 1935): 2-9. (My translation.) 
Hu was averse to partisanship and to a political process based on the representation of competing interests. Hu wrote in 1935:

We may expect that in the future Chinese politics will not experience enthusiastic competition among political parties. If we examine the national crisis of the past four years, we see that as national consciousness increases, partisanism declines. This is not merely a Chinese phenomenon... Far-sighted statesmen should seize upon this tendency to create a consciousness of "nation above all" and a national, supraparty politics (chāodăngpài de zhèngzhì). ${ }^{104}$

$\mathrm{Hu}$ wanted the Nationalists "to move from one-party government to nonpartisan government, and in this way to establish a political style in China that might serve as a model to the world..."105 Later in life, $\mathrm{Hu}$ Shi wrote We Must Choose Our Own Way, published in 1949, in which he addresses the function of opposition parties:

Standing opposite to the ruling party, the opposition party aims at first to supervise the government in establishing the strictest evaluating and supervising organization; secondly, to offer the opportunities for the people to make choices so that the political power of the nation will be transferred through a legal way. Strict evaluation and supervision, peaceful transference of political power are the ways leading to peaceful reformation for a modern democratic country. 106

$\mathrm{Hu}^{\prime}$ 's tendency to hope for the government to form policies based on common interests, in the wake of warlordism, perhaps is understandable. Nonetheless, it seems surprising that $\mathrm{Hu}$ so often discounted the dynamic of competing interests in politics. "Supraparty politics" is rather

${ }^{104} \mathrm{Hu}$, "Cong Yidang Dao Wudang de Zhengzhi." (From One Party to Nonpartisan Politics.) Duli Pinglun 171 (Oct. 6, 1935): 10-12. (My translation.) 105 Hu, "Cong Yidang Dao Wudang de Zhengzhi." (My translation.) 106 Yang 101. 
authoritarian, as any government formed on "common interests" is going to reflect the "common interests" of only a few.

While $\mathrm{Hu}$ was bitingly critical of the Nationalist government, he was a reformer rather than a revolutionary and was willing to work with what was available. In this direction, he continuously insisted upon the writing of a permanent constitution as a first step toward political order and democracy. He contended, reminiscent of Liang Qichao's views on constitutionalism, that the establishment of a constitution would make the Nationalist government stronger by making it legitimate. At the same time, however, $\mathrm{Hu}$ did conceive of constitutionalism as the establishment of a rule of law, meaning that the government would have to abide by the law. In the Independent Critic, he wrote:

Constitutional democracy is nothing but to set a rule as a scope within which government and its people can have political activities. Both government and people must observe the rule within this scope. It is thus called constitutional government. It is also called constitutional democracy because any capable citizen is permitted to participate in politics, to express his personal opinions, to operate politics by proper means......Constitutional government means a political system in which all concerned are required to observe law, namely, it is law-abiding politics. ${ }^{107}$

The launching of the "New Life Movement" by the Nationalist Party in 1934 underscored a major division between Hu Shi and the Nationalists. The New Life Movement, partly in response to the antitraditionalism of the Chinese Communists, aimed to restore the value of Confucianism, from extolling frugality to proposing tips on personal hygiene. While Hu valued many aspects of Confucian virtue, he was 
exasperated by the Nationalists' opposition to intellectual innovation, the only path towards modernity in Hu's view. Hu rightly saw this movement, telling the people to brush their teeth and not to spit in public, as superficial and incapable of leading to true progress. Furthermore, he angrily viewed the Confucian revival as a revocation of the intellectual progress that had been achieved in recent decades:

Pitiful and despairing old revolutionary party! You wanted a revolution, but now that the revolution has achieved these twenty years of unprecedented progress, you disown it. What progress there has been in these two decades was not a gift from Confucius, but the result of a common revolutionary struggle, the result of a common acceptance of the new civilization of a new world. Our only hope lies in moving forward. 108

Though $\mathrm{Hu}$ was often criticized for advocating "total Westernization," he did not equate modernization with Westernization. He frequently criticized Chinese cultural traditions, often bitterly, but he did not intend to repudiate the whole tradition. He aimed to provoke his compatriots to think critically about different aspects of Chinese tradition in order to evaluate its particular usefulness in the modern world.

What pessimistic observers have lamented as the collapse of Chinese civilization, is exactly the necessary undermining and erosion without which there could not have been the rejuvenation of an old civilization. Slowly, quietly, but unmistakably, the Chinese Renaissance is becoming a reality. The product of this rebirth looks suspiciously occidental. But, scratch its surface and you will find that the stuff of which it is made is essentially the Chinese bedrock which much weathering and corrosion have only made stand out more clearly -- the humanistic and rationalistic

${ }^{108}$ Greider, Hu Shih 284. 
China resurrected by the touch of the scientific and democratic civilization of the new world. ${ }^{109}$

Hu left Beijing in early July 1937, just before China plunged into its darkest days of war after fighting broke out between Japanese and Chinese troops near the Marco Polo Bridge in Beijing. Soon after, the Japanese invaded Shanghai and Nanjing. Finally $\mathrm{Hu}$ Shi realized that a peaceful settlement was not possible, and he officially proclaimed his allegiance to the Nationalists in the name of preserving the state. ${ }^{110}$ In mid-September, Hu left China as a semi-official emissary to plead China's case in the United States and Europe. He spent all but seven of his remaining twentyfive years abroad, returning to Beijing as Chancellor of Beijing University from 1946 to 1948 and finally residing in Taiwan from 1958 until his death in 1962. His years abroad were spent representing the Nationalists' case in America, as well as America's position to Nationalist leaders. He lectured to academic and civic groups in the United States, often speaking of his hopes for democratic progress in China, and attended the founding conference of the United Nations in San Francisco in 1945 as a member of the Chinese delegation. Even during some of the most desperate years when war all but stalled China's modern development, Hu Shi remained a steadfast proponent of democratic principles in society and politics.

${ }^{109} \mathrm{Hu}$, preface, The Chinese Renaissance.

${ }^{110}$ Greider, $\mathrm{Hu}$ Shih 293. 


\section{CHAPTER 4: CONCLUSION \\ DEMOCRACY AND MODERNITY}

Liang Qichao and Hu Shi represent two generations of political change and intellectual development in China. The development of democratic ideas in China can be followed through the ideas of Liang and $\mathrm{Hu}$ and the modernizing trends of their respective generations, in which the definition of modernity changed from one characterized by concerns with political transition to one that emphasized cultural transformation as the foundation of modern China. The differences in their concepts can be linked to the specific challenges that their particular generations faced as well as their own personalities.

For Liang and $\mathrm{Hu}$ and others like them, democracy for China signified modernity. Modernization was the paramount objective, so the definition of democracy and the details of its potential implementation changed over time as the definition of modernization changed. For Liang Qichao's generation, modernization entailed the transformation of the political system for the strengthening of the nation and thus, Liang deliberated the usefulness of democracy in a constitutional monarchy and later in the establishment and building of the Republic. Hu Shi's generation was disappointed with the failure of the 1911 Republican Revolution's political transition to propel China's progress, and its definition of modernity meant a democratic transformation in the cultural environment and in social conditions. 


\section{Democracy, Modernity and Political Reform}

Liang Qichao came of age at a time when knowledge of Western ideas was only beginning to seep into intellectual circles in China. Periods of reform in previous dynasties had meant the reinterpretation and reinvigoration of Confucian concepts, and reform in the latter half of the 1800s still meant reform within the Confucian tradition. The urgency of studying Western scientific and technological expertise had been recognized as early as the 1860s, but the belief in the superiority of Chinese culture and social and political institutions dominated. Liang and other progressive intellectuals of the 1890s had to overcome this Confucian mind-set in order to push for the consideration of Western-style political reforms.

The inclusion of Western ideas of democracy in political modernization in China began with Kang Youwei and Liang Qichao's Petition of 1895. Their evolving definition of modernity was motivated by the proven inadequacy of the early modernizing scheme of the $1860 \mathrm{~s}$ and 1870s Self-Strengthening Movement. Japan and the strongest Western nations not only possessed technologically advanced weapons, but also possessed what Chinese observers perceived as democratic political institutions in which citizens and groups outside officialdom had an influence. The few Chinese who had traveled to Europe, America, or Japan reported on the energetic involvement of their citizens in all realms of life, including politics. In the Chinese view, these nations derived their strength and modernity from the vigorous involvement of their people in public life, whether it meant an educated person holding a government 
post or an ordinary citizen reading the newspapers to keep up with current national and international events; this involvement the Chinese observers roughly understood as democracy. They decided that this kind of democratic energy could activate China's modernization.

Liang's generation, reformers and revolutionaries at their peak of activity between the 1895 Petition and the 1911 fall of the imperial system, can be characterized similarly by their commitment to political change and their role as political activists. They were "animated by the spirit of political entrepreneurship"1 and strongly believed in the value of transforming political institutions as a way of renovating the Chinese nation. They broke with their predecessors, the Confucian reformers of the nineteenth century, in forming political associations with other likeminded intellectuals and in entertaining a variety of ideas of Western political systems, most notably, democratic systems.

Whether reformers or revolutionaries, they shared an urgent concern with the survival of the Chinese nation, and agreed that the first objective was political change built on a politically aware and participatory population. Liang's contribution to China's development was in the realm of political organization and arousing nationalist propaganda, reflecting the activities considered most important by his generation. His involvement in drafting the 1895 Petition, organizing study societies, and writing and editing the new-style political journals of his time were his most noteworthy activities. Through these modern study societies and

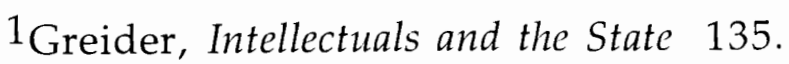


political journals, he was an early conduit of foreign ideas to his Chinese audiences.

Liang's theme of "new citizens" was sounded in the literature of reformers and revolutionaries alike. The political activists of Liang's generation were confident that political change would effect the corresponding social transformation on which to build a modern China. Liang's recurrent points became definitions of modernity for his generation and beyond: individuals overcoming a subservient nature (pointed out by this generation and later ones as a negative aspect of China's traditional culture) to one of a free citizen, building a united citizenry for a foundation of a stronger state, progress, struggle, and the rethinking of Chinese traditions and values. His prescription for democracy can be linked directly to all of these themes: his idea of democracy was meant to arouse, educate, and unite Chinese citizens for the purpose of strengthening and modernizing the Chinese nation to enable it to face the international struggle.

So for the first time in China, the 1895 protest and the following study societies and political journals aimed to inspire and encourage the activity of a wider population than was historically involved in political deliberations. ${ }^{2}$ Modernizing political institutions meant democratizing

${ }^{2}$ Kang and Liang focused their attention on the urban gentry and merchants, and while this is still rather elitist, it was a move in a more popular direction. The rural population did not receive significant attention until the late 1920s and '30s when Mao Zedong turned the attention of the Chinese Communist Party to arousing the peasant masses for political action. Mao later developed his own definition of participatory democracy, the basis of which can certainly be traced to Liang's ideal of a united and politically active citizenry. Mao did read Liang's New 
them, and this meant broadening political involvement by creating a politically aware citizenry who could restore the link between the ruler and ruled and revitalize the political institutions. Liang's political journals served to educate his new citizens through the diffusion of new, modern values. The study of political values and institutions was traditionally the preserve of the elite who aspired to pass the civil service examinations and acquire a government post and the corresponding privileges. While traditionally the literati studied and wrote in classical Chinese, Liang's political journals were written partially in the vernacular so that anyone with a level of functional literacy could read them and consider the newest political ideas of the day. This was Liang's democratic mode for creating "new citizens" for a modern China.

Liang Qichao and most of his generation had been educated primarily in the Confucian tradition, and naturally they continued to use much of its vocabulary and political values to discuss Western methods of political reform. The idea of a politically active citizenry was modern, but Liang defined his new citizens in a way that blended tradition and modernity. For example, Liang affirmed the value of freedom and people's rights, but he saw the relationship between the state and the individual as harmonious and free of contention. In Liang's conception, freedom was

Citizen as a youth, stating that he "worshipped Kang and Liang", but in later years he dismissed Liang's generation of reformers as "bourgeois democrats." (Nathan 63) For more on Mao's definition of democracy, see the translation of his speech "On the People's Democratic Dictatorship" in Selected Readings from the Works of Mao Tse-tung (Peking: Foreign Languages Press, 1971) 371-388 and Nathan's Chinese Democracy, footnoted above. 
intended to liberate the natural tendencies of individuals to educate themselves, and then they would naturally recognize their interest in uniting with fellow citizens for the common good. Liang wrote in 1900:

Those who entertain no idea of self-benefit must inevitably abandon their rights, abdicate their responsibilities, and ultimately lose their independence....In the West there is a saying to the effect that Heaven helps him who helps himself. No calamity in life is greater than the failure to help oneself, hoping only that help will be forthcoming from others... But no man can survive alone in the world, and for this reason the community comes into existence. Living within the community, among one's fellows, it is of course impossible to live completely to oneself, paying no heed to the question of whether something beneficial to oneself may harm others...Thus those best able to benefit themselves must first be of benefit to the community. From this will follow benefit to themselves. ${ }^{3}$

Internal competition, that between individual citizens or between the citizens and the state, was negative in Liang's mind. It was necessary for Liang's educated and politically aware citizens to be united to strengthen China for the international struggle for freedom, freedom from the domination of outside groups. It is clear that Liang's conception of democracy, a united and politically active citizenry, was inseparable from his ideal of a modern China that was strong and united.

Though Liang did not subscribe to the virulent anti-Manchu nationalism that many of the revolutionaries of the time propounded, there was a similarity of purpose to political reform between Liang and his more radical contemporaries. Liang was wary of revolution and the destructive and chaotic forces that might follow. He was wary, especially after his trip in 1903 to America and his observation of Chinese

${ }^{3}$ Greider, Intellectuals and the State 165. 
communities there, of putting responsibility for the government in the hands of an uneducated public. For Liang and his generation, the most important duty at hand was the strengthening of the nation; reformers and revolutionaries alike wavered between a variety of plans for nationbuilding, some including an aspect of democracy and others postponing the instituting of democracy for a future date when conditions were deemed ready. During his brief period advocating "enlightened despotism" upon his return from the United States, he visualized his fellow citizens in a struggle for modernization, "those born in the thundering tempests of today, forged and molded by iron and fire -- they will be my citizens, twenty or thirty, nay, fifty years hence. Then we will give them Rousseau to read and speak to them of Washington." Though Liang changed his mind at times about the specifics of democratic institutions he desired and how soon democratic institutions could be implemented, democracy remained in his vision of a modern China.

During the movement for a constitutional monarchy in the last years of the Qing empire, Liang reiterated his belief in the positive energy of the people in supervising the government. However, Liang did not intend to institute methods by which outside political forces could weaken the central government. He saw democracy as a way to strengthen the nation by uniting the people and the government. Because these new citizens would have a voice and an influence, a modern democratic concept, the government would be compelled to respond to this positive energy. Hence the government and the people would be united in modernizing and strengthening the nation. 
With the establishment of the Republic in 1912, Liang continued to strive for gradual democratic reform and modernization. He continued to put his faith in political change as a means to modernization, but the next generation changed the emphasis of democratization to focus on social and cultural development.

\section{Democracy, Modernity and Cultural Reform}

Hu Shi came of age twenty years after Liang, in the 1910s, and the demise of the Confucian imperial system was already a fact. Since his schooling in Shanghai starting at age 12 in 1904, the fall of the imperial system was imminent, and Hu was exposed early on to many ideas from the West. The worth and potential of foreign-inspired methods and ways of thought was, by the time of his study in the United States, widely accepted among young intellectuals of Hu's generation.

Hu Shi's experiences in the United States made a deep and lasting impression on his personality and way of thought. Liang Qichao had been depressed by his visit to the United States in 1903; he felt that China was decades behind the United States, politically and economically, and was extremely discouraged by the condition of Chinese living in America. The imperialism that characterized American foreign policy at that time reinforced Liang's commitment to Chinese nationalism and its necessity for the modernization and strengthening of China. Hu Shi, on the other hand, arriving in the United States in 1910, was inspired by the optimism of Americans and their faith in progress. His stay in the United States corresponded with the era of Woodrow Wilson's idealism and 
internationalism, and certainly this climate underlay $\mathrm{Hu}^{\prime}$ s cosmopolitan outlook, his commitment to pacifism, and his belief that nations can work together for the common good of humankind.

$\mathrm{Hu}^{\prime} \mathrm{s}$ time in the United States also allowed him to develop his strong commitment to democratic ideas apart from an immediate concern for the survival of China. Until 1937 when the war with Japan finally became too grave, Hu continuously pushed for democratic reforms on the basis of the ideals of independent thinking and reason. Hu had a more Western conception of human rights than Liang Qichao, who maintained that the interests of the people remain subordinate to that of the state. Even though a concern for the progress of China was still at the forefront of their thoughts, $\mathrm{Hu}$ and others of his generation were inclined to judge individual interests as valuable on their own, perhaps reflecting their own personal and intellectual detachment from society but also reasoning that modernity must be achieved person by person before society and nation can be modernized.

$\mathrm{Hu}$ Shi can be associated with the New Culture Movement, roughly dated 1915-1927; this period does not have events demarcating ending and beginning, like Liang's generation with the 1895 Petition and the 1911 Revolution, but it does have the pivotal 1919 May Fourth Movement at its center. Liang's generation of reformers and revolutionaries had attributed China's weakness to the failings of the Confucian state and the Manchu rulers. The debate of Liang's generation, while new and progressive for its time, had still been conducted largely under Confucian terms of renovating the relationship between ruler and ruled. But by 1915, the 
failure of the founding of the Republic to make China strong had become distressingly apparent, and this next generation of intellectuals, to which Hu belonged, felt that the political debates of the previous generation had missed the mark. They felt that not only had the old Confucian system repressed the political energies of the people but that it had also perpetuated and entrenched an oppressive social order and ignored a vital popular culture. Thus, in order to achieve modernity for China, political revolution became secondary to a social and cultural movement.

Hu Shi represented the May Fourth generation's emphasis on cultural revitalization over political reform in the task of China's modernization. In 1958, he wrote that "throughout my adult life I have always taken what I prefer to call a disinterested interest in politics as a civic duty of an educated man." 4

To me, democracy is a way of life, a habit of behavior, and science is a method, a method of thinking and knowing. Both Science and Democracy involve an attitude of mind or a habit of behavior, a way of living. 5

Hu Shi's attitude of mind seems well-suited to the ideals of democratic debate. He approached the study of problems systematically and pragmatically, open to new ways of looking at things that encouraged reasoned deliberation. Modern scientific methodologies allowed a reevaluation of Chinese history and cultural traditions. Modernity, for both Liang and $\mathrm{Hu}$, involved re-thinking previously held assumptions, and like Liang's criticism of the traditional value of passive endurance, $\mathrm{Hu}$

${ }^{4} \mathrm{Hu}$ Shih, Reminiscences of $\mathrm{Dr}$. Hu Shih (Microfilm. New York: Columbia University, East Asian Institute, 1959) 38.

${ }^{5} \mathrm{Hu}$ Shih, Reminiscences 194. 
criticized his fellow Chinese for having "never been willing to think, and only know(ing) how to conform, without holding opinions of our own." Whereas Liang valued education for its ability to arouse a politically aware population, $\mathrm{Hu}$ valued education for its capacity to generate questions and advocate critical thinking. The spirit of democracy, for $\mathrm{Hu}$, encouraged a variety of opinions and ideas, and in this way, a modern, reasoning, knowledge-seeking public would develop. He believed that modernization rested in social education.

Like Liang's protest of 1895, the principal event of Hu Shi's New Culture generation, the protest of May 4, 1919, reinforced the idea that protest is a justifiable expression of the people's concern with political events. However, the event also evolved into a rejection of the idea that political reform or even revolution could modernize China. The May Fourth generation was understandably disaffected from politics. This disaffection, however, spurred the exploration of an even wider investigation into new ideas beyond politics and on to culture and society. Confucianism was criticized in nearly all its aspects, especially now its social and cultural traditions.

Hu Shi's leadership in the literary revolution reflected the new emphasis on modernizing China's culture and social environment. As part of this generation's attack on the Confucian social order, the literary movement aimed to break down social barriers between the elite and the general population, a kind of cultural and educational democratization in literature. Foreshadowing this movement of the 1910s were Liang Qichao's political journals of the previous decades; they too were written 
partially in the vernacular in order to arouse a wider audience to political awareness and action. Liang approved the extenuation of the vernacular to the literary realm, writing:

To renovate the people of a nation, the fictional literature of that nation must first be renovated. Thus to renovate morality, we must first renovate fiction,... to renovate learning and the arts, we must first renovate fiction, and even to renew the people's hearts and minds and remold their character, we must first renovate fiction. 6

Hu Shi insisted that he was not creating something new but that vernacular literature had been a vital and indigenous art for centuries, from the vernacular novels of the Ming and Qing to the informally written dialogues of Zhu Xi and other Neo-Confucian thinkers of the Song period. However, elevating the vernacular to the status of high art was a new development with wide cultural and social implications. Hu was convinced this was necessary for China's cultural and social modernization, for he argued that unless the vernacular language became the universal language of the new culture, the consequence would be "to divide society into two classes: on the one side, 'we,' the gentry; and on the other side, 'they,' the common people, the masses."7 In Hu Shi's own words, the literary revolution was "a movement of reason versus tradition, freedom versus authority, and glorification of life and human values versus their suppression." Recognizing the worth of reason, freedom and human values were, for $\mathrm{Hu}$, in the spirit of democracy and

${ }^{6}$ C.T. Hsia, "Yen Fu and Liang Ch'i-ch'ao as Advocates of New Fiction." In Adele A. Rickett, ed. Chinese Approaches to Literature from Confucius to Liang Ch'i-ch'ao (Princeton: Princeton University Press, 1978) 222-223.

${ }^{7}$ Greider, Intellectuals and the State 230. 
modernization and reflect his generation's preoccupation with social and cultural progress. "Democracy...is no more and no less than the sum total of all the democratized and democratizing forces, social, economic, moral, and intellectual."

In the political realm, Hu's advocacy of constitutionalism and other political proposals was characterized by a more Western orientation than Liang's ideas had been, reflecting both personal differences and differences in their generations. Because $\mathrm{Hu}$ abandoned his Confucian education and was introduced to Western ideas at an early age, he was freed from relying on Confucian vocabulary. Moreover, Hu's years in the United States unquestionably had a lasting influence on his ideas about politics. His sense of distance from the political arena probably stemmed both from his time away from China and the New Culture generation's detachment from politics.

While Liang had maintained that a constitution would strengthen the state because the interests of the state would naturally coincide with individual interests, $\mathrm{Hu}$ Shi understood constitutionalism in an American way. He held that the purpose of a constitution would be to limit the government's authority, and that it meant the establishment of the rule of law. Hu Shi did believe in a strong government -- "a government with a plan" -- yet he did not uphold the need for a period of political tutelage, as Liang had. He believed that the best way to have democracy "was to have democracy;" he admitted that leadership in government took some sophisticated knowledge, but that the average person's participation did not. He held that having democracy would be an educative process in 
itself and gradually the base of a progressive, enlightened populace would emerge and a modern China would evolve. As Jerome Greider put it, $\mathrm{Hu}$ Shi "was disposed to think of democracy less as a specific institutional system than as a state of mind, an extension into the sphere of political and social life of the tolerant and critical spirit of science, though he did not slight the importance of democratic institutions as a means of preventing political abuse and insuring the preservation of sufficient standards of political, social, and intellectual liberty." 8

\section{Constant Democratic Trends between Liang and $\mathrm{Hu}$}

Both Liang Qichao and Hu Shi advocated opening participation in politics by a much wider spectrum of the population than had previously been involved. Liang Qichao, as a leader (with Kang Youwei) of the 1895 Petition, was a pioneer in this respect, as this was the first time that people without government posts attempted to influence government policy. This was a revolutionary proposal, and though the protesters in $1895 \mathrm{did}$ not achieve their demands, the idea that people outside the government structure had a role to play in politics was soon widely accepted, even though the nature of their role remained (and still remains) disputed.

Liang and Hu both believed that education was the key to modernization for its ability to arouse awareness and widen participation in politics and public life in general. As intellectuals, their roles were that of educators. Liang's conception of new citizens did address cultural and social issues by his criticism the Confucian-encouraged tendency for people 
to passively accept fate rather than to actively strive for a better future.

This social and cultural critique was meant to serve the primary purpose of political renewal, but it was a first step towards the wider social and cultural criticism of $\mathrm{Hu}$ Shi and his generation, when social and cultural transformation became the fundamental concern. Both Liang and $\mathrm{Hu}$ considered their thoughts democratic because their ideas entailed popular participation in modernizing society and political institutions.

Liang and $\mathrm{Hu}$ both were drawn to democracy as a means to modernize and strengthen the Chinese nation, but the difference between Liang's focus on national strength and Hu's more cosmopolitan viewpoint corresponds with wider political and cultural events as well as their own personal backgrounds. Liang and his generation concentrated their efforts on modernizing the political structure, and thus the value of democracy was in its blueprint for political modernization. $\mathrm{Hu}$ and his generation moved beyond the political realm to attend to modernization in the social and cultural order. Democracy for Hu's generation meant modernization not only in politics but in all other aspects of life as well.

In their educational roles, both Liang and $\mathrm{Hu}$ transmitted foreign ideas through their writings to other young Chinese intellectuals. They prompted their fellow citizens to look at China and the world in a new way. They criticized the traditional Chinese values of passivity, subservience, and conformity as one reason behind China's national and international predicament, and argued that these characteristics were incompatible with the modern world. They both consciously blended 
tradition and modernity in their interpretations of democratic reforms and in their prescriptions for modernization.

While much of their work can be called revolutionary, in that it contributed much to the revolutionary causes of their times, neither Liang nor $\mathrm{Hu}$ were revolutionaries themselves. They were moderates, committed to gradual (though profound) change, wary of and dismayed by the chaos caused by their more radical contemporaries. Though they both bitterly criticized the governments under which they worked, they both preferred to reform the existing power structure rather than overthrow it. They both believed that education would naturally cause their compatriots to unite to work for the common good of the Chinese society and nation.

Even though many of Liang's and Hu's particular prescriptions for reform ultimately lost out to more radical forces, their influence was far broader and long-lasting than any one political or social movement. Ideas that were new in Liang's time, such as the importance of nationalism and the idea that modernization meant more than acquiring scientific expertise, were taken for granted by Hu's time. Hu expanded on the work that Liang had done, in the realms of education and in the progression of the conception of modernization and democracy to include cultural and social transformation. The link between modernization and democracy was firmly established, even though the intellectuals of their times and later wavered between whether democracy led to modernization or whether modernization led to democracy. 


\section{EPILOGUE}

China of the 1990s continues to struggle with its definitions of democracy and modernity in much the same way as Liang Qichao and $\mathrm{Hu}$ Shi had. The goal of China's Communist Revolution remains the attainment of an independent modern society and nation, and the various social and political campaigns since 1949 have continued to reflect this highest national purpose.

The democratic ideal of a politically active citizenry has remained one of the most important political values throughout the Communist era (though, of course, one would question the democratic nature of mass participation orchestrated by the highest levels of government). The enduring importance of political activism reflects the lasting belief that an active citizenry will strengthen and modernize the nation. And while critical thought and free expression have not been encouraged under Communist rule, it seems clear from the periods during which unapproved criticisms were expressed, such as the Hundred Flowers Movement (1957), Democracy Wall (1978-79), and the protests of the late 1980s, that critical thinking and free expression remain an ideal of intellectuals and others. These brief intervals also show that spontaneous protest from outside the ranks of officialdom is still considered, by many Chinese, a patriotic demonstration of concern for the conditions of society and nation. 
Democracy continues to be one of the most powerful words used by Chinese who discuss their nation's progress. China's leaders speak of democracy as a kind of spirit or feeling which unifies citizens and leaders to work together for the common good. The fact that leaders as well as dissidents feel the need to use the term democracy to discuss China's society and politics reveals the power of the word. While there is disagreement among Chinese officials, youth, and other citizens about what democracy is, exactly, it is agreed that democracy is necessary for China's modernization.

Some Chinese see democracy in a more concrete way, as a system which can ensure involvement by ordinary people and their influence on government procedures. Though there are some contemporary Chinese who value democracy for its protection of individual rights, the majority still speak of its higher potential for strengthening the nation. Most of the 1989 Tiananmen Square protesters were not revolutionaries, seeking the overthrow of the Chinese Communist Party, but were reformers, hoping to curb bureaucratic corruption, open government procedures to public supervision, and loosen government controls of the press. The demonstrations illustrated the breakdown in the relations between the rulers and ruled and the desire of the educated youth, and others, not to weaken the government but to make it stronger by repairing communication between the government and the people and pushing for a greater influence on public policy by ordinary citizens.

It is safe to say that in the 1990s, the social, economic, and political distance between the rulers and ruled in China is continuing to widen, as 
the Deng Xiaoping (1904- ) era of the 1980s and '90s brings great prosperity to some and leaves others far behind. The definitions of democracy

continue to be reassessed as China faces the latest challenges of modernization. 
GLOSSARY

Liáng Qǔchāo

Hú Shì

àihù zìjî de quánlì

báihuà

Bǎohuáng Huì

chángshí de zhèngzhì

dìngzhāng

Gāoděng Dàtóng Xuéxiào

gèrén xìng

gōngchē

gōngkāi de zhèngfǔ

guómín

Guómíndăng

jísī guăngyì

Jìnbù Dăng

Jìngyè Xúnbào

kāimíng zhuāngzhì

käiwù dìzàng

míndé

mínlì

mínzhī
粱启超

胡适

爱护自己的权力

白话

保皇会

常识的政治

定章

高等大同学校

个人性

公车

公开的政府

国民

国民党

集思广益

进步党

竞业白报

开明专制

开吾地藏

民德

民力

民知 
Nưlì Zhōubào

qǐsî shéndān

Qiáng Xuéhuì

Qingyì Bào

quán

qún

réndào zhǔyì

Shíwù Bào

Shíwù Xuétáng

shù

shùrén

tèbié yīngjié de zhèngzhì

tūiguăng zhèngquán
努力周报

起死神丹

强学会

清议报

权

群

人道主义

时务报

时务学堂

术

树人

特别英杰的政治

推广政权

Wú qiè wèi wèi č̃ yánzhě qú bù zhì yì yì shèn yǐ

xī xué weì ť̃, zhōng xué wèi yòng

Xiàndài Pínglùn

Xiànyǒu Hù̀

Xinyuè

xíngshi

Xīnmín Shuō

Xingzhōng Hù

yìshì

yìshì zhīrén

yơusī
吾窃谓为此言者其不智抑已甚矣

西学为体，中学为用

现代评论

宪友会

新月

行事

新民说

兴中会

议事

议事之人

有司 
Zhèngwén Shè

Zhīxīn Bào

Zhōngguó Gōngxué

Zhōngwài Gōngbào

zixin

ziyóu
政闻社

知新报

中国公学

中外公报

自新

自由 


\section{BIBLIOGRAPHY}

\section{Primary Sources}

Gannet, Lewis. "Hu Shih: Young Prophet of Young China," The New York Times Magazine (March 27, 1927): 10.

Hu Shih. The Chinese Renaissance. 2nd Edition. New York: Paragon Book Reprint Corp., 1963.

---. The Development of the Logical Method in Ancient China. 2nd. Edition. 1922. New York: Paragon Book Reprint Corp., 1963.

---. The Reminiscences of Dr. Hu Shih. New York: Columbia University, East Asian Institute, 1959. (Microfiche.)

---. "Aiguo Yundong Yu Qiuxue." (The Patriotic Movement and Scholarly Pursuits.) In Sharon Shi-juan Hou and Chih-ping Chou, eds. $\mathrm{Hu}$ Shi Reader: An Advanced Reading Text for Modern Chinese. 171198. New Haven, Conn.: Far Eastern Publications, 1990.

---. "The Civilizations of East and West." In Charles A. Beard, ed. Whither Mankind: A Panorama of Modern Civilization. 25-41. New York: Longmans, Green and Co., 1928.

---. "Communications to American Editors on Japanese Demands: Letter to The New Republic." The Chinese Students' Monthly 10:6 (March 1915): 389-390.

---. "Cong Yidang Dao Wudang de Zhengzhi." (From One Party to Nonpartisan Politics.) Duli Pinglun (Independent Critic) 171 (Oct. 6, 1935): 10-12.

--.. "Instrumentalism as a Political Concept." In Studies in Political Science and Sociology. 1-6. Philadelphia: University of Pennsylvania Press, 1941.

---. "Intellectual China in 1919." The Chinese Social and Political Science Review 4:4 (December 1919): 345-355. 
---. "A Plea for Patriotic Sanity: An Open Letter to All Chinese Students." The Chinese Students' Monthly 10:7 (April 1915): 425-426.

---. "The Renaissance in China." Journal of the Royal Institute of International Affairs 5:6 (November 1926): 265-283.

---. "Untitled Essay." In Living Philosophies: A Series of Intimate Credos. 235-263. New York: Simon and Schuster, 1931.

--. "Wenti yu Zhuyi." (Problems and Isms.) In Sharon Shih-juan Hou and Chih-ping Chou, eds. Hu Shi Reader.: An Advanced Reading Text for Modern Chinese. 149-170. New Haven, Conn.: Far Eastern Publications, 1990.

---. "Zai Lun Jianguo Yu Zhuanzhi." (Another Discussion of National Reconstruction and Authoritarianism.) Duli Pinglun (Independent Critic) 82 (Dec. 24, 1933): 2-5.

---. "Zhengzhi Gaige de Dalu." (The Great Road Toward the Reform of Political Institutions.) Duli Pinglun (Independent Critic) 163 (Aug 11, 1935): 2-9.

Liang Qichao. "Zengzhi Yu Renmin." (Politics and the People.) In Yingbing Shi Heji (The Complete Works from the Ice-Drinker's Studio) 3 (20): 17-18.

"Yin Yan." (Editorial Introduction.) Duli Pinglun (Independent Critic) 1 (May 22, 1932): 2.

Secondary Sources

Chang, Hao. Liang Ch'i-ch'ao and Intellectual Transition in China, 18901907. Cambridge: Harvard University Press, 1971.

Chou, Min-chih. Hu Shih and Intellectual Choice in Modern China. Ann Arbor: University of Michigan Press, 1984.

Chow, Tse-tung. The May Fourth Movement: Intellectual Revolution in China. Cambridge: Harvard University Press, 1960. 
DeBary, William Theodore, Wing-Tsit Chan, and Chester Tan, eds. Sources of Chinese Tradition. Vol. 2. New York: Columbia University Press, 1960.

Duara, Prasenjit. "De-constructing the Chinese Nation." Australian Journal of Chinese Affairs 30 (July 1993): 1-26.

Gasster, Michael. "Reform and Revolution in China's Political Modernization." In Mary Clabaugh Wright, ed. China in Revolution: The First Phase, 1900-1913. 67-96. New Haven: Yale University Press, 1968.

Greider, Jerome B. Hu Shih and the Chinese Renaissance: Liberalism in the Chinese Revolution, 1917-1937. Cambridge: Harvard University Press, 1970.

--. Intellectuals and the State in Modern China. New York: The Free Press, 1981.

Hsia, C. T. "Yen Fu and Liang Ch'i'ch'ao as Advocates of New Fiction." In Adele. A. Rickett, ed. Chinese Approaches to Literature from Confucius to Liang $\mathrm{Ch}^{\prime} i-\mathrm{ch}^{\prime}$ ao. 221-257. Princeton: Princeton University Press, 1978.

Huang, Philip C. Liang Ch'i-ch'ao and Modern Chinese Liberalism. Seattle: University of Washington Press, 1972.

Levenson, Joseph R. Liang Ch'i-ch'ao and the Mind of Modern China. New York: Harper and Row, 1959.

Nathan, Andrew J. Chinese Democracy. New York: Knopf, 1985.

---. Peking Politics, 1918-1923: Factionalism and the Failure of Constitutionalism. Berkeley: University of California Press, 1976.

Schneider, Lawrence A. Ku Chieh-kang and China's New History: Nationalism and the Quest for Alternative Traditions. Berkeley: University of California Press, 1971.

Schwarcz, Vera. The Chinese Enlightenment: Intellectuals and the Legacy of the May Fourth Movement of 1919. Berkeley: University of California Press, 1986. 
Schwartz, Benjamin I. "Culture, Modernity, Nationalism -- Further Reflections." In Tu Wei-ming, ed. China in Transformation. 233253. Cambridge: Harvard University Press, 1994.

Shin, Tim Sung Wook. The Concepts of State (Kuo-Chia) and People (Min) in the Late Ch'ing, 1890-1907: The Case of Liang Ch'i-Ch'ao, T'an Ssu-t'ung and Huang Tsun-hsien. Ph.D dissertation. University of California, Berkeley, 1980.

Sun, Lung-kee. "Historians' Warp: Problems in Textualizing the Intellectual History of Modern China." Positions: East Asian Cultural Critique 2:2 (Fall 1994): 355-381.

T'ang, Leang-li, ed. China's Own Critics: A Selection of Essays by Hu Shih and Lin Yu-tang, with Commentaries by Wang Ching-wei. Hu Shih and Lin Yu-tang translated from Chinese. New York: Paragon Book Reprint Corp., 1969.

Teng, Ssu-yu and John K. Fairbank, eds. China's Response to the West: A Documentary Survey. New York: Antheneum, 1975.

Wong, Frank Fe. Liang Ch'i-chao and the Conflict of Confucian and Constitutional Politics. Ph.D. dissertation. University of Wisconsin, Madison, 1965.

Yang, Cheng-pin. The Political Thoughts of Dr. Hu Shih. Translated from Chinese. Taipei, Taiwan: Bookman Books, 1986.

Young, Ernest P. "The Reformer as Conspirator: Liang Ch'i-ch'ao and the 1911 Revolution." In Albert Feuerwerker, Rhoads Murphy, and Mary C. Wright, eds. Approaches to Modern Chinese History. 239267. Berkeley: University of California Press, 1967. 